\begin{tabular}{l|l|l|l|l|}
$\begin{array}{l}\text { Journal of } \\
\text { Endocrinology }\end{array}$ & $\begin{array}{l}\text { A E Céspedes Rubio, } \\
\text { M J Pérez-Alvarez et al. }\end{array}$ & $\begin{array}{l}\text { Dual roles of sex steroid } \\
\text { hormones in stroke }\end{array}$ & $\mathbf{2 3 7 : 2}$ & $\mathbf{R} 65-$ R81
\end{tabular}

REVIEW

\title{
Sex steroid hormones as neuroprotective elements in ischemia models
}

\author{
Ángel Enrique Céspedes Rubio1,*, Maria José Pérez-Alvarez²,3,4, Catalina Lapuente Chala5 and \\ Francisco Wandosel|3,4
}

'Departamento de Sanidad Animal, Grupo de Investigación en Enfermedades Neurodegenerativas, Universidad del Tolima, Ibagué, Colombia 2Departamento de Biología (Fisiología Animal), Facultad de Ciencias, Universidad Autónoma de Madrid, Madrid, Spain

${ }^{3}$ Centro de Biología Molecular 'Severo Ochoa', Departamento de Neuropatología Molecular CSIC-UAM, Madrid, Spain ${ }^{4}$ Centro de Investigación Biomédica en Red sobre Enfermedades Neurodegenerativas (CIBERNED), Madrid, Spain

${ }^{5}$ Grupo de Investigación en Enfermedades Neurodegenerativas, Investigador Asociado Universidad del Tolima, Ibagué, Colombia

Correspondence should be addressed to F Wandosell: fwandosell@cbm.csic.es

*(A E Céspedes Rubio and M J Pérez-Alvarez contributed equally to this work)

\section{Abstract}

Among sex steroid hormones, progesterone and estradiol have a wide diversity of physiological activities that target the nervous system. Not only are they carried by the blood stream, but also they are locally synthesized in the brain and for this reason, estradiol and progesterone are considered 'neurosteroids'. The physiological actions of both hormones range from brain development and neurotransmission to aging, illustrating the importance of a deep understanding of their mechanisms of action. In this review, we summarize key roles that estradiol and progesterone play in the brain. As numerous reports have confirmed a substantial neuroprotective role for estradiol in models of neurodegenerative disease, we focus this review on traumatic brain injury and stroke models. We describe updated data from receptor and signaling events triggered by both hormones, with an emphasis on the mechanisms that have been reported as 'rapid' or 'cytoplasmic actions'. Data showing the therapeutic effects of the hormones, used alone or in combination, are also summarized, with a focus on rodent models of middle cerebral artery occlusion (MCAO). Finally, we draw attention to evidence that neuroprotection by both hormones might be due to a combination of 'cytoplasmic' and 'nuclear' signaling.

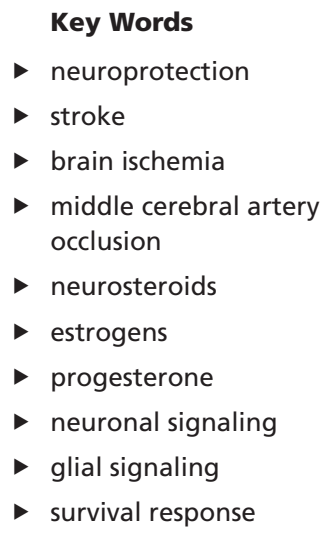

Journal of Endocrinology (2018) 237, R65-R81

\section{Introduction}

Estrogens and progestogens are the main female sexual hormones, both mainly synthesized and secreted to the blood by the ovaries (under pituitary control) and placenta and produced by the adrenal glands in both males and females. They have an important function in reproduction; in females, the gonads are the highest contributors to blood levels of progestogens and estrogens before menopause (Konings et al. 2017). Among estrogens, estradiol (17- $\beta$-estradiol) is considered to be the principal compound with estrogenic action (Hoffman 2006, Perez-Alvarez \& Wandosell 2016) whereas progesterone, $5 \alpha$-dihydroprogesterone and allopregnanolone are considered the main progestogens (Perez-Alvarez \& Wandosell 2016).

All estrogens and progestogens are derived from cholesterol; the synthesis pathway first generates pregnenolone, which is afterward converted to progesterone, testosterone and subsequently to estradiol. 
The last step in this pathway, the conversion of androgens to estrogens, is catalyzed by aromatase, which is expressed in different tissues including the brain (Azcoitia et al. 2017). The tissue availability of estrogens and progestogens depends on circulating levels of both hormones, but is also determined by local, de novo synthesis in various nonreproductive tissues, including the brain (Guennoun et al. 2015, Konings et al. 2017). Indeed some of the enzymes responsible for the synthesis of estradiol have been described in neurons and glial cells (Pelletier 2010).

Due the fact that some brain cells have the capacity to locally synthesize them, estrogens and progestogens are not only 'neuroactive steroid' compounds, but can be considered 'neurosteroids'.

\section{Physiological action of estradiol in the brain}

In addition to reproductive functions (Sinchak \& Wagner 2012), estrogens can modulate important brain functions in males and females including cognition, learning and memory, mood, pain and nociception (Roselli 2007). These physiological effects are due to the ability of estradiol to generate substantial changes in neuronal physiology and morphology of key brain areas such as the hippocampus, striatum, amygdala, cortex and hypothalamus, among others (Carrer \& Aoki 1982, Korol \& Pisani 2015).

It is known that all the cellular components of the central nervous system (neurons, glial cells and endothelial cells) are targets of estradiol, which regulates neuronal and glial cell differentiation in various brain areas like the hypothalamus (Díaz et al. 1992, Lenz \& McCarthy 2010), midbrain (Beyer \& Karolczak 2000), cerebellum (Tsutsui 2006, 2012), hippocampus (Bender et al. 2010) and neocortex (Hu et al. 2007), among others.

In addition, numerous reports have confirmed a substantial neuroprotective role for estradiol in models of neurodegenerative diseases, but the focus of this review is on traumatic brain injury and stroke models (PérezAlvarez \& Wandosell 2013, Engler-Chiurazzi et al. 2016, Melcangi et al. 2016, Perez-Alvarez \& Wandosell 2016).

Most of the studies involving estrogenic actions in the brain have focused on neurons. Many studies indicate that estradiol controls important mechanisms that regulate neuronal maturation and differentiation, such as axonal and dendritic development, growth of dendritic spines and the establishment of synapses (Arevalo et al. 2012). However, the underlying molecular mechanism implicated in each of these developmental activities of estradiol is not necessarily identical; it is possible that the mechanism depends on neuronal type and/or brain region, and specific repertoires of hormone receptors. Also, since estradiol can be synthesized by neurons and glia, these actions may be mediated by paracrine or autocrine mechanisms (Kretz et al. 2004, Von Schassen et al. 2006, Hu et al. 2007, Fester et al. 2009). It has been established that brain levels of aromatase are a reliable indicator of the amount of brain-derived estradiol. Under physiological conditions in mammals, amphibians, reptiles and birds, aromatase is located mainly in neurons (Coumailleau et al. 2014). However, in teleost fish, aromatase has been detected principally in radial glia (Forlano et al. 2001).

Estradiol has an important impact on brain development and normal physiology, but also after injury. Cellular targets of its action are both neurons and the main glial cell types (astrocytes, microglia, radial glia and oligodendrocytes) (Pérez-Álvarez et al. 2012, PérezAlvarez \& Wandosell 2013). After brain injury, ischemia or hypoxia, levels of aromatase (and consequently estradiol) increase in the damaged area, especially in astrocytes and radial glia, but also in neurons (Garcia-Segura et al. 1999, Peterson et al. 2001). Nowadays, this neurosteroid is considered to have an important role in neuroprotection, acting locally through a rapid mechanism of action (see below) (Garcia-Segura et al. 1999, Pedersen et al. 2016). One of the estradiol-mediated neuroprotective mechanisms is the significant reduction of neuroinflammation, a common effect after brain trauma or injury that exacerbates initial damage (reviewed in Perez-Alvarez \& Wandosell 2016). Several studies have demonstrated in mammals and birds that the anti-inflammatory effect of estradiol plays a protective role, positive when local estradiol production in astrocytes is increased after upregulation of aromatase expression or negative when its activity is inhibited (Garcia-Segura et al. 1999, Pedersen et al. 2016).

\section{Estradiol receptors: 'classical' and "non-classical' pathways}

Estrogens initiate biological actions by binding specific proteins named estradiol receptors (ERs), which are classified into two main groups. The first, known as the 'classical' ERs (ER $\alpha$ and ER $\beta$ ), belong to the nuclear receptor superfamily and act as nuclear transcription factors (Hewitt et al. 2010). The second group, 'nonclassical' ERs (G-protein-coupled estradiol receptors), are membrane-associated receptors responsible for rapid and non-genomic estrogenic action, including GPER1 
(also known as GPR30) and Gq-mER. Although GPER1 is a transmembrane receptor, it has also been reported on intracellular compartments, such as the endoplasmic reticulum (Revankar et al. 2005, Thomas et al. 2005, Filardo et al. 2007, Alexander \& Harvey 2017), whereas Gq-mER was originally identified in hypothalamic neurons. Their function is poorly understood, but seems to have a modulatory role in HPA axis (Qiu et al. 2008, Nag \& Mokha 2014, Hu et al. 2016).

'Classical' ERs have been detected in the extranuclear compartment; in fact, ER $\alpha$ was identified on the plasma membrane of neurons and astrocytes (Dominguez \& Micevych 2010, Azcoitia et al. 2011). ER $\alpha$ can also interact with other membrane receptors, generating macromolecular complexes that allow for synergy with other growth factors. Regarding the cell types expressing ERs, our research group and others have reported that both neurons and glial cells express ER $\alpha$ and ER $\beta$ (Varea et al. 2010). The expression of GPR30 in neurons and astrocytes has been demonstrated using pharmacological approaches (Lee et al. 2012, Tang et al. 2014), though the presence of Gq-mER in glial cells has not been fully demonstrated. Many reports have indicated that, at least in the mammalian brain, neurons and glia respond specifically to estradiol through ERs, even though the exact contribution of ER $\alpha$, ER $\beta$, GPR30 and Gq-mER in each neural cell type has not been established (Shughrue et al. 1997, Toran-Allerand et al. 1999, Hübner et al. 2015).

Similar to ER classification, the estrogenic mechanisms of action in target tissues are sorted into 'classical' (transcription-dependent) and 'nonclassical' (cytoplasmic-dependent, receptor-independent antioxidant actions) (Mann et al. 2007). 'Classical' pathways are nuclear actions regulated by 'classical ERs', in which the main effect is to regulate gene expression at a transcriptional level. The interaction of estrogens and ERs forms a homodimeric or heterodimeric complex that binds to specific DNA sequences called estrogen response elements (ERE), activating gene expression (Pettersson et al. 1997). Estrogen-ER complexes can also interact with other nuclear receptor coactivators or repressors (Gruber et al. 2002) (summarized in Fig. 1). Usually, slow effects with long-term actions, typical of a steroidal hormone response, characterize this pathway.

The 'non-classical' pathway is characterized by rapid effects mediated by membrane-associated ERs, with a critical role in the nervous system and neuroprotection (Toran-Allerand et al. 2002, Raz et al. 2008). In fact, estradiol may activate different signaling pathways such as MAPK/Erk (Singh et al. 1999), PI3K/Akt (Honda et al. 2000),
PKA (Prossnitz \& Barton 2011) or PKC (Cordey et al. 2003), thus regulating multiples genes and neuronal functions including apoptosis/survival. Some of these actions may be attributed to the G-protein-coupled receptor (GPR30), but not all (Filardo \& Thomas 2005, Prossnitz et al. 2007, 2008) (summarized in Fig. 1). In addition, estrogens have been reported to present receptor-independent antioxidant actions (Pajović \& Saičić 2008).

Our group has demonstrated that ERo interacts with the PI3K regulatory subunit p85 in the brain and primary neuron cultures, coupled in this way to the 'cytoplasmic signaling' of insulin-like growth factor 1 receptor (IGF1R). The interaction between $\mathrm{ER} \alpha$ and $\mathrm{p} 85$ is associated with GSK3 phosphorylation and $\beta$-catenin stabilization (Cardona-Gomez et al. 2004). This macromolecular complex in neurons may contain ER $\alpha$, IGF1R and some components of IGF1R downstream signaling such as phosphoinositide 3-kinase (PI3K), AKT, glycogen synthase kinase $3 \beta$ (GSK3 $\beta)$ and $\beta$-catenin. The complex is sensitive to IGF-1 and estradiol, with effects in neurons and glia that allow synergistic action between them (Mendez et al. 2003, Alonso et al. 2008, Garcia-Segura et al. 2010, Arevalo et al. 2012).

As mentioned earlier, estradiol activates $\beta$-cateninmediated transcription through the PI3K-AKT-GSK3 signaling pathway (Varea et al. 2009, 2010, 2013). Inhibition of GSK3 $\beta$ activity is a common mechanism of neuroprotection initiated by several factors, such as Wnt, IGF-1, neurotrophins and estradiol. In addition, it has been reported that estradiol activates $\beta$-cateninmediated transcription through the canonical WNT signaling pathway, which is activated when WNT binds its co-receptors (low-density lipoprotein-related protein 5 (LRP5), LRP6 and Frizzled), and negatively regulated by Dickkopf 1 (DKK1). Some reports have indicated that estradiol upregulates WNT signaling by inhibiting expression of DKK1 (Zhang et al. 2008, Scott et al. 2012). Whether both estradiol effects (via GSK3 phosphorylation/ $\beta$-catenin stabilization and DKK-1derived effects) are sequential events or not must be more deeply analyzed (some of these data are schematically represented in Fig. 1).

\section{Physiological action of progesterone in the brain}

As mentioned earlier, progestogens are neurosteroids that are generated locally in the nervous system, as different areas of the brain and spinal cord express the enzymes 


\begin{tabular}{l|l|l|c|}
$\begin{array}{l}\text { Journal of } \\
\text { Endocrinology }\end{array}$ & $\begin{array}{l}\text { A E Céspedes Rubio, } \\
\text { M J Pérez-Alvarez et al. }\end{array}$ & $\begin{array}{l}\text { Dual roles of sex steroid } \\
\text { hormones in stroke }\end{array}$ & $\mathbf{2 3 7 : 2}$ \\
\hline
\end{tabular}

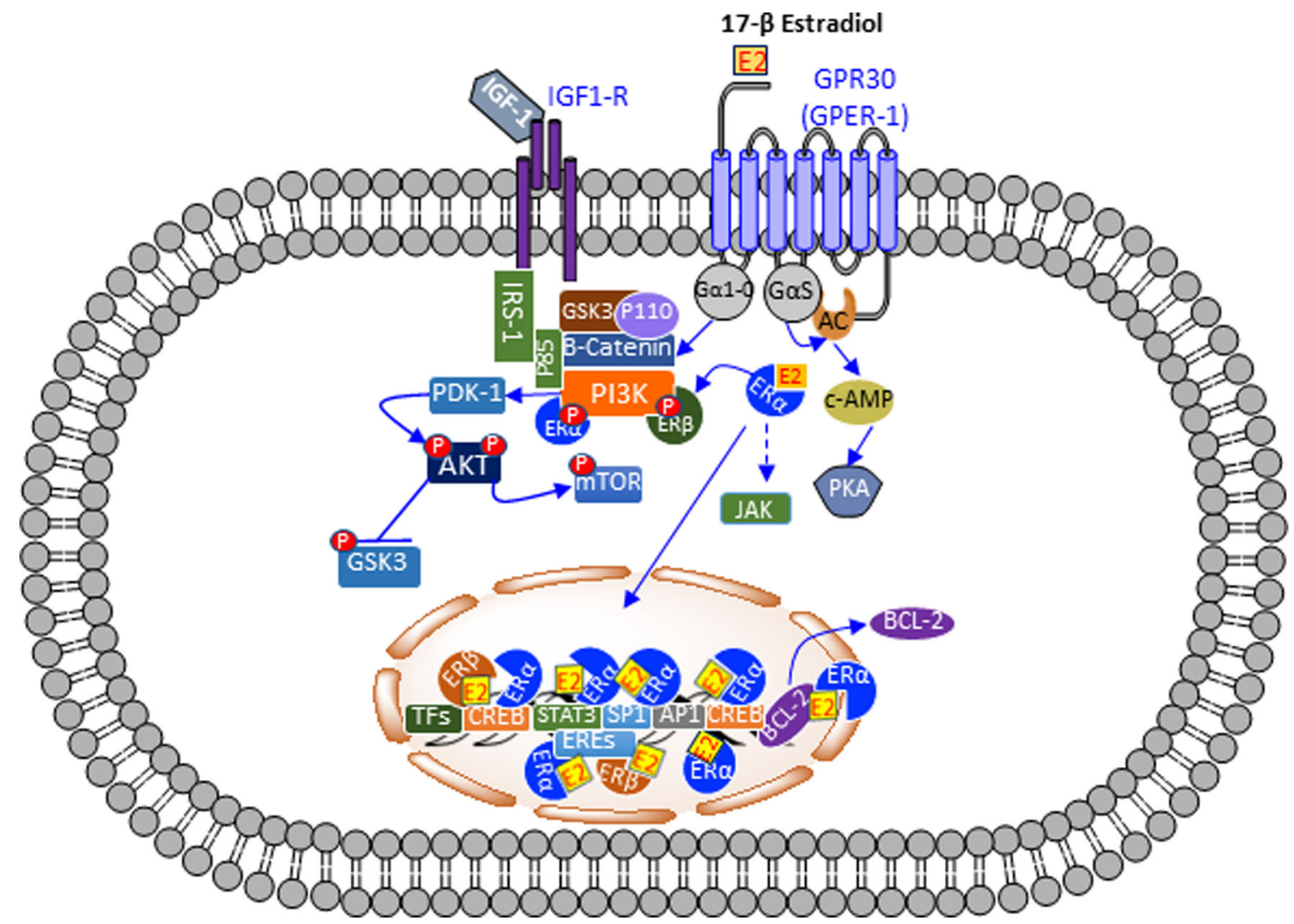

Figure 1

Schematic representation of classical and non-classical pathways of estrogen receptors (ERs). 17- $\beta$-estradiol is represented as E2. The 'classical receptors', $E R \alpha$ and ER $\beta$, after linking E2, form complexes that act as transcription factors by direct binding with specific DNA regions (EREs) (either homo or heterodimeric) or by binding to some co-transcriptional activators (CREB, STAT, SP1, etc.), dependent on different signals: Expression and activation of multiple targets, such as BCL-2, may play a key role in neuroprotective actions, although the complete molecular mechanisms remain to be elucidated. Some elements of the IGF1/IGFR pathway were represented. These classical receptors (ER $\alpha$ and/or ER $\beta$ ) may form a complex with the regulatory element of PI3K class I, p85 in conjunction with GSK3/ $\beta$-catenin. The binding of E2 to ERs in this complex finally stabilizes $\beta$-catenin, which may act as a

co-transcriptional factor in the nucleus, similar to Wnt signaling. Besides the membrane-bound estrogen receptor GPR30 trigger a cytoplasmic signaling through the activation of Gi and/or Gs proteins, acting on PKA, PI3K or JAK kinases among others. A full color version of this figure is available at https:// doi.org/10.1530/JOE-18-0129.

required for progesterone and allopregnanolone synthesis (Do Rego et al. 2012, Melcangi et al. 2014, Schumacher et al. 2014, Guennoun et al. 2015), in both neurons and glial cells (Guennoun et al. 2015).

In neurons, progesterone regulates differentiation, synaptic plasticity, dendritic remodeling and neurogenesis (Woolley \& McEwen 1993, Giachino et al. 2003, Foy et al . 2008). In glial cells, it contributes to differentiation and proliferation of astrocytes (Luquin et al. 1993, Jung-Testas et al. 1999, Arbo et al. 2016), oligodendrocytes (Ghoumari et al. 2005), and microglia (Roche et al. 2016) and plays a key role in myelinogenesis (Deutsch et al. 2013). It should be noted, that some of the effects observed after progesterone administration may be triggered by their derivative, allopregnanolone (for a review see: Noorbakhsh et al. 2014, Guennoun et al. 2015).

http://joe.endocrinology-journals.org https://doi.org/10.1530/JOE-18-0129
In addition, progesterone plays a role in neuroprotection after stroke, reduces neuroinflammation and decreases reactive gliosis, among other effects (Brinton et al. 2008, Deutsch et al. 2013, Arbo et al. 2016, PerezAlvarez \& Wandosell 2016).

\section{Progesterone and its receptors}

The biological actions of progestogens are initiated by their binding to specific receptors, all of them expressed in the central nervous system (Guennoun et al. 2015). Similar to estradiol, progesterone receptors can be grouped into two main families: the 'classical' progesterone receptors (PRs), PR-A and PR-B, that belong to the nuclear receptor superfamily of transcription factors (Kastner et al. 1990); and membrane-associated receptors (mPR and the 
PGRMC1 complex) that can stimulate rapid intracellular signaling. In addition, modulation of GABA-A receptor activity by allopregnanolone has a direct impact on neuronal activity, related to neuroprotection and pain modulation (Sitruk-Ware \& El-Etr 2013, Afrazi \& EsmaeiliMahani 2014, Schumacher et al. 2014, Huang et al. 2016). A single gene that differentially expresses several subdomains encodes classical PRs, including a variable N-terminal region, a conserved DNA-binding domain, a variable hinge region, and a conserved ligand-binding domain. PR-B, the longer isoform, contains an additional $\mathrm{N}$-terminal region that is missing in PR-A, known as the B-upstream segment (BUS), which represents an additional activation region (Conneely et al. 1987, Diaz Brinton 2012). Some short isoforms (PR-A) have been described lacking the DNA-binding domain and nuclear localization signal (NLS) (Hirata et al. 2002); it has been proposed that these shorter versions may function as cytoplasmic signaling elements, alone or coupled with membrane-associated PRs (see below).

Regarding mPRs, five isoforms have been described to-date: $\mathrm{mPR} \alpha, \mathrm{mPR} \beta, \mathrm{mPR} \gamma, \mathrm{mPR} \delta$ and $\mathrm{mPR} \varepsilon$ (Zhu et al. 2003a, Pang et al. 2013), all of which are 7-transmembrane proteins that activate $G$ proteins. They are members of the progestin and adipoQ receptor (PAQR) family, rather than members of the $G$ protein-coupled receptor superfamily (Thomas \& Pang 2012). All mPR mRNAs are expressed in the central nervous system at variable levels (Zuloaga et al. 2012, Meffre et al. 2013, Pang et al. 2013, Schumacher et al. 2014). $\mathrm{mPR} \alpha$ has been found in neurons and is strongly induced in some glial cell (astrocytes, oligodendrocytes and microglia) after local injury, indicating a potential modulatory role in neuroinflammation (Meffre et al. 2013, Guennoun et al. 2015).

PGRMC1 is another less-known component of membrane PRs, mostly expressed in the spinal cord, hypothalamus, ependymal cells, circumventricular organs and meninges (Meyer et al. 1996, Meffre et al. 2005, Labombarda et al. 2013, Guennoun et al. 2015). After local injury, PGRMC1 expression increases in neurons and astrocytes (Meffre et al. 2005, Guennoun et al. 2008).

\section{Mechanism of action of progesterone}

Based on the two described groups of PRs, and similar to estrogens, the mechanisms of progesterone action can be divided into 'classical' and 'non-classical'. The 'classical' mechanism is triggered by PRs and is characterized by its slow action: progesterone binding to a PR induces receptor dissociation from chaperones, homo- or hetero-dimerization, and finally activation of gene transcription. This activity is mediated by direct binding to progesterone response elements (PREs) in the promoter region of target genes (Schumacher et al. 2014). Current data emphasizes the importance of recruitment of coactivators like SRC1, SRC2 and SRC3, among others. The transcriptional activities of nuclear receptors are modulated in a positive or negative manner, depending on the availability of coactivators or corepressors (York \& O’Malley 2010, Amazit et al. 2011, Schumacher et al. 2014). This increases the complexity of understanding the mechanisms of progesterone, because the response is not only dependent on progesterone and PRs, but also coactivators/corepressors that have variable expression and distribution throughout the brain. In addition, the supplementary relationship between PR-A and PR-B increases the complexity of this transcriptional system (Brayman et al. 2006, Aupperlee \& Haslam 2007).

Both receptor groups, PRs and mPRs initiate the 'non-genomic or rapid' actions of progesterone. PRs are able to activate kinases such as MAPK, PI3K, CDK and c-SRC in a direct manner (by association with cytosolic kinases) or indirectly through binding to membrane-associated complexes (Migliaccio et al. 1998, Boonyaratanakornkit et al. 2001, Schumacher et al. 2014). This extranuclear signaling of PRs may play a key role in neurons, as some evidence shows PR localization in axons, dendrites and synapses (far from the nucleus), highlighting the possible role of PRs in neuronal activity and excitability (Schumacher et al. 2014). The five mPR types allow for differential signaling, the best known being direct interaction with protein Gs or Gi, resulting in activation (in $\mathrm{mPR} \alpha, \operatorname{mPR} \beta$ and $\operatorname{mPR} \gamma$ ) or inhibition (in $\mathrm{mPR} \delta$ and $\mathrm{MPR} \varepsilon$ ) of the MAPK pathway through modulation of cAMP production (Zhu et al. 2003b, Thomas 2008). mPR $\alpha$ (via MAPK activation) has been implicated in the anti-apoptotic effects of progesterone (Pang et al. 2013). Knowledge about the mechanism of action of PGRMC1 is poor, though a recent report related PGRMC1 activation by progesterone to neuroprotection through the release of BDNF by astrocytes ( $\mathrm{Su}$ et al. 2012) (summarized in Fig. 2).

Obviously, there exists some cross-talk between extranuclear and classical intracellular signaling pathways, which must be taken into account to understand the full mechanism of action of progesterone (Mani \& Oyola 2012). It is also very important to remember the close relationship between progesterone and allopregnanolone, which is a potent activator of the GABA-A receptor, enhancing the inhibitory transmission of GABA with 


\begin{tabular}{l|l|l|l|l|}
$\begin{array}{l}\text { Journal of } \\
\text { Endocrinology }\end{array}$ & A E Céspedes Rubio, & Mual roles of sex steroid & $\mathbf{2 3 7 : 2}$ & $\mathbf{R 7 0}$ \\
hormones in stroke
\end{tabular}

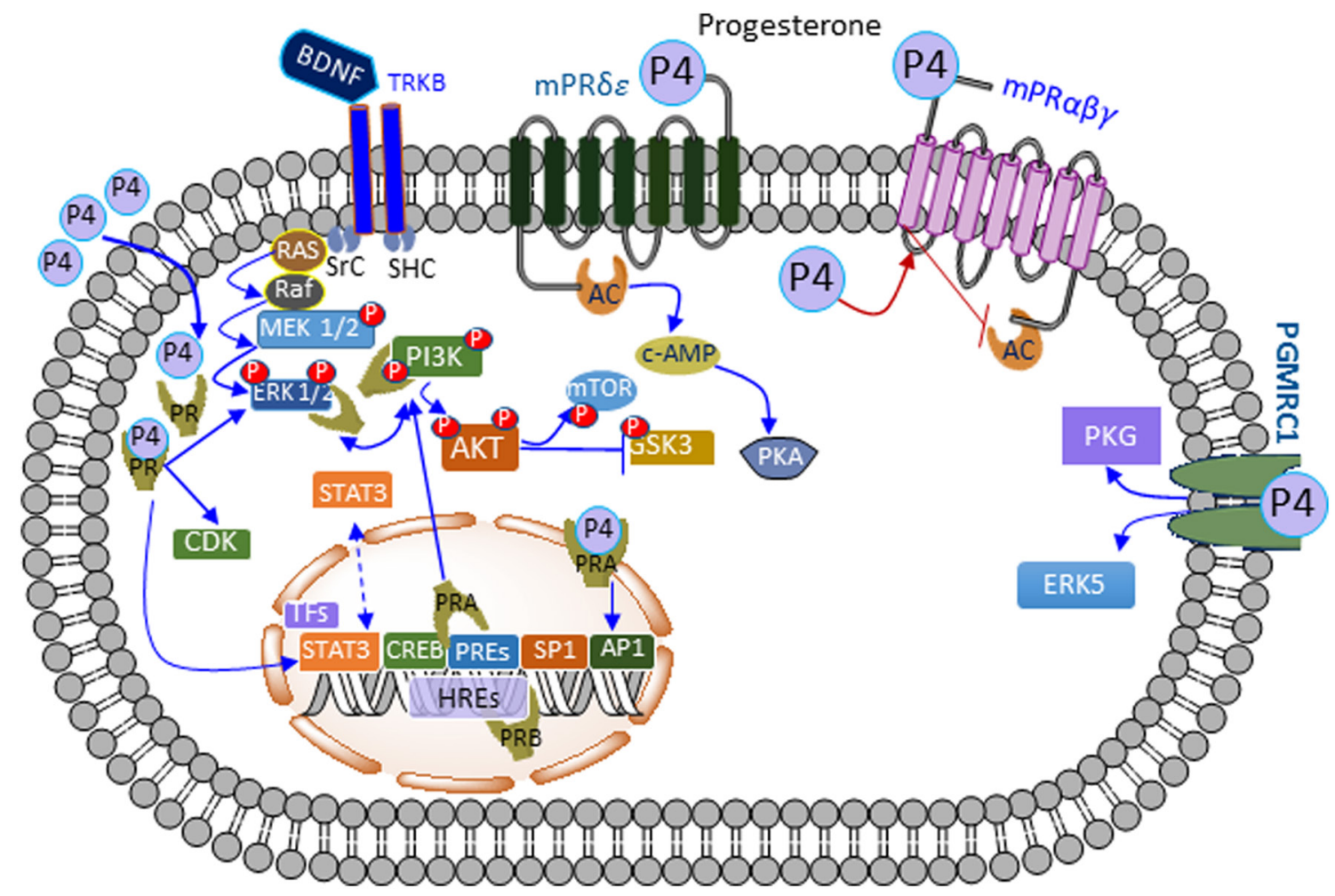

\section{Figure 2}

Schematic representation of classical and non-classical pathways mediated by progesterone receptors (PRs). Progesterone is represented as (P4). The 'classical' progesterone receptors (PRs) PR-A and PR-B belong to the superfamily of nuclear receptors and that activate genes for transcriptional regulation, by direct binding to specific DNA regions (HREs) or bind to co-transcriptional activators (such as, CREB, STAT, SP1, etc.). Some data indicated that PR A and/or B may triggered or boost MAP kinase signaling, directly or indirectly. Besides this nuclear transcriptional regulation, progesterone receptors located on the plasma membrane (mPRs) that activate intracellular signal have been described. Accordingly mPR $\delta$ and mPR $\varepsilon$ may activate PKA, via adenylate cyclase (AC), whereas $\mathrm{mPR} \alpha / \beta / \gamma$ may inactivate $A C$. In addition a different membrane-associated receptor denoted as PGMRC1 have been reported and may act as a co-receptor to trigger rapid intracellular signals (such as Erk5 or PKG). A full color version of this figure is available at https:// doi.org/10.1530/JOE-18-0129.

additional physiological consequences (Belelli et al. 2006, Hosie et al. 2006).

\section{Therapeutic effects of estradiol and progesterone: synergists or antagonists?}

In general, neurosteroids (particularly progesterone and estradiol) have been considered neuroprotective, shown by various animal models of neurodegenerative diseases, stroke, spinal cord damage and traumatic brain injury (Perez-Alvarez \& Wandosell 2016, Schumacher et al. 2016). However, for several reasons, this idea does not always correspond well to the therapeutic effect observed in patients, so the use of estradiol and progesterone in humans remains a controversial subject.

In fact, the reduction of sex hormones in women during normal aging has been associated with the brain's vulnerability to some diseases (Merchenthaler et al. 2003), supporting that female sex hormones are neuroprotective agents. Indeed, there is a lot of evidence in the human population to consider estradiol and progesterone as neuroprotective. The normal age-related decline of female sex hormones during menopause is strongly related to greater incidence of certain diseases including neurodegenerative and cardiovascular disorders and stroke. The onset and severity of neurodegenerative disease has a marked difference between the sexes, being especially evident at menopause. In fact, menopause is considered a risk factor for stroke (Wise 2003) among other neurodegenerative disorders (Xu et al. 1998, Simpkins et al. 2005, Bourque et al. 2009, Schreihofer \& Ma 2013). Although the circulating levels of both estradiol and progesterone progressively decrease during menopause, the neuroprotective effect is mainly attributed to estradiol, probably due to the fact that blood-estradiol levels in adult women are higher than progesterone.

This decline in neuroprotection may have several reasons, not only due to the reduction in circulating 
estradiol; it has been reported that estradiol receptors (ER $\alpha$ and ER $\beta$ ) present age- and menopause-related differences. Thus, increasing age was associated with decreasing ER $\alpha$ and ER $\beta$ expression (Park et al. 2017). Indeed, it is well accepted that ER $\alpha$ expression is autoregulated by estradiol, which may explain a lower level of receptors in some brain regions, associated with age and with some pathologies such as Alzheimer's disease (AD) (Wijayaratne \& McDonnell 2001, Mott \& Pak 2013, Wang et al. 2016).

Thus, it is tantalizing to propose that even considering the capacity of astrocytes to overexpress aromatase, the reduction of ERs may generate a lower sensitivity to response during aging and menopause. Thus, diminishing levels of circulating estrogen in postmenopausal women, coupled with a reduction of brain estrogen receptors, may contribute to the inflammatory state that is a hallmark of many neuropathologies (Yague et al. 2006, Luchetti et al. 2011, Medway et al. 2014).

Further, in vitro and in vivo models have demonstrated the beneficial effects of estradiol administration preor post-injury for some diseases including glutamate excitotoxicity (Hilton et al. 2006), stroke (Pérez-Álvarez et al. 2012), neuroinflammation (Perez-Alvarez \& Wandosell 2016) or $\mathrm{AD}$ (Xu et al. 1998). It is interesting to note that some of the beneficial effects of estradiol after brain injury can be attributed to direct anti-inflammatory effects on glial cells after local synthesis (Bruce-Keller et al. 2000, Baker et al. 2004, Vegeto et al. 2006, 2008, PérezÁlvarez et al. 2012) (Pedersen et al. 2016).

Similar to estradiol, progesterone is considered a neuroprotective mediator (De Nicola et al. 2006, Sayeed \& Stein 2009, Guennoun et al. 2015), with positive effects after damage including reduction of inflammation after traumatic brain injury (Pettus et al. 2005), decreased oxidative damage (Roof et al. 1997), protection of neurons from excitotoxicity (Smith 1991) and recovery of mitochondrial dysfunction (Irwin et al. 2008). In addition, there are many similarities between the actions of progesterone and estrogen, such as their signals and targets. In spite of this, the underlying mechanism of action of estradiol- or progesterone-mediated neuroprotection remains unclear. There are surprisingly few studies and clinical trials using a combination of estradiol and progesterone, and they have shown mixed results.

Some experiments revealed a synergistic or additive effect of combined administration of estradiol and progesterone compared with estradiol alone, such as preventing cell death via diminution of apoptosis (Nilsen \& Brinton 2002b) or improving myelination in autoimmune encephalomyelitis (Garay et al. 2008). However, other reports indicated a non-synergistic or even antagonistic effect, seemingly contradictory results which may be reasonable because in almost all cases of combination treatment, the positive response reported for estradiol were reduced or almost blocked by progesterone (Aguirre \& Baudry 2009, Lorenz et al. 2009, Yao et al. 2011, Maki \& Henderson 2012, Perez-Alvarez et al. 2015). In long-term experiments, it is important to remember that progesterone modulates the availability of ERs (Aguirre et al. 2010) and that estradiol regulates the differential expression of PRs (Acharya et al. 2015). Moreover, it is well known that prolonged treatment with estradiol increases the risk of some hormone-dependent cancers, and in these cases, the combination with progesterone may be critical to reduce undesirable estrogenic side effects. Another factor to consider is the time of action, perhaps using short-term vs long-term treatments to enhance synergistic neuroprotective effects, as has been suggested for $\mathrm{AD}$ in women (Wharton et al. 2011, Shao et al. 2012).

\section{Estradiol and progesterone: therapeutic effects in stroke models}

Ischemic stroke is a complex neurodegenerative disease with high global prevalence, being the second-leading cause of death and the leading cause of disability (Mozaffarian et al. 2016). Human epidemiological data show a marked gender difference related to incidence and prognosis of stroke: Men have higher incidence and worse prognosis for stroke than women do until menopause, at which point the pattern is reversed (Scott et al. 2012, Mozaffarian et al. 2016). Therefore, statistical data suggest that sex hormones play a pivotal role in brain damage after stroke, and studies in animal models sustain this notion. For instance, in age-matched rats, females had less serious brain injury than males after induction of cerebral ischemia, while ovariectomized females presented more brain damage than intact females or even males (Alkayed et al. 1998b, Rusa et al. 1999, Inagaki \& Etgen 2013).

The pathophysiological events triggered after cerebral ischemia, termed 'ischemic cascade', have been determined using animals models. Middle cerebral artery occlusion (MCAO) is one of the most extensive in vivo models used for research, and may be transient (tMCAO) or permanent (pMCAO), depending on the duration of occlusion (Sawada et al. 2000). The ischemic cascade is composed of highly time-dependent phases including energetic failure, excitotoxicity, peri-infarct depolarizations, neuro-inflammation and cell death that 
may be necrotic or programmed (apoptosis) (Dirnagl et al. 1999; Pérez-Alvarez \& Wandosell 2013) (summarized in Fig. 3). Neuroprotective agents against ischemia block or reduce some aspects of this ischemic cascade. There is evidence that some of the pathological actions of the ischemic cascade are modulated by estradiol and/or progesterone (Perez-Alvarez et al. 2015). However, although more than 1026 potential neuroprotective drugs have been tested in animals with promising results, at present none have been successful in humans (Jickling \& Sharp 2015).

The neuroprotective effects of estradiol administration alone have been widely described in stroke models
(Sawada et al. 2000). Blood-estradiol levels are inversely correlated with infarct size after ischemia induction (Liao et al. 2001), and the described positive effects of estradiol also occur it is exogenously administered before or after ischemia, in both males and females (Alkayed et al. 1998a, Dubal et al. 1998, Toung et al. 1998, Pérez-Álvarez et al. 2012). As indicated earlier, brain-estradiol levels are very dependent on local synthesis by aromatases, and after ischemic injury, the expression of aromatase increases mainly in astrocytes (McCullough et al. 2003, Carswell et al. 2005, Scott et al. 2012, Pedersen et al. 2016).

One of the beneficial actions of estradiol in the ischemic cascade is modulation of the neuroinflammation

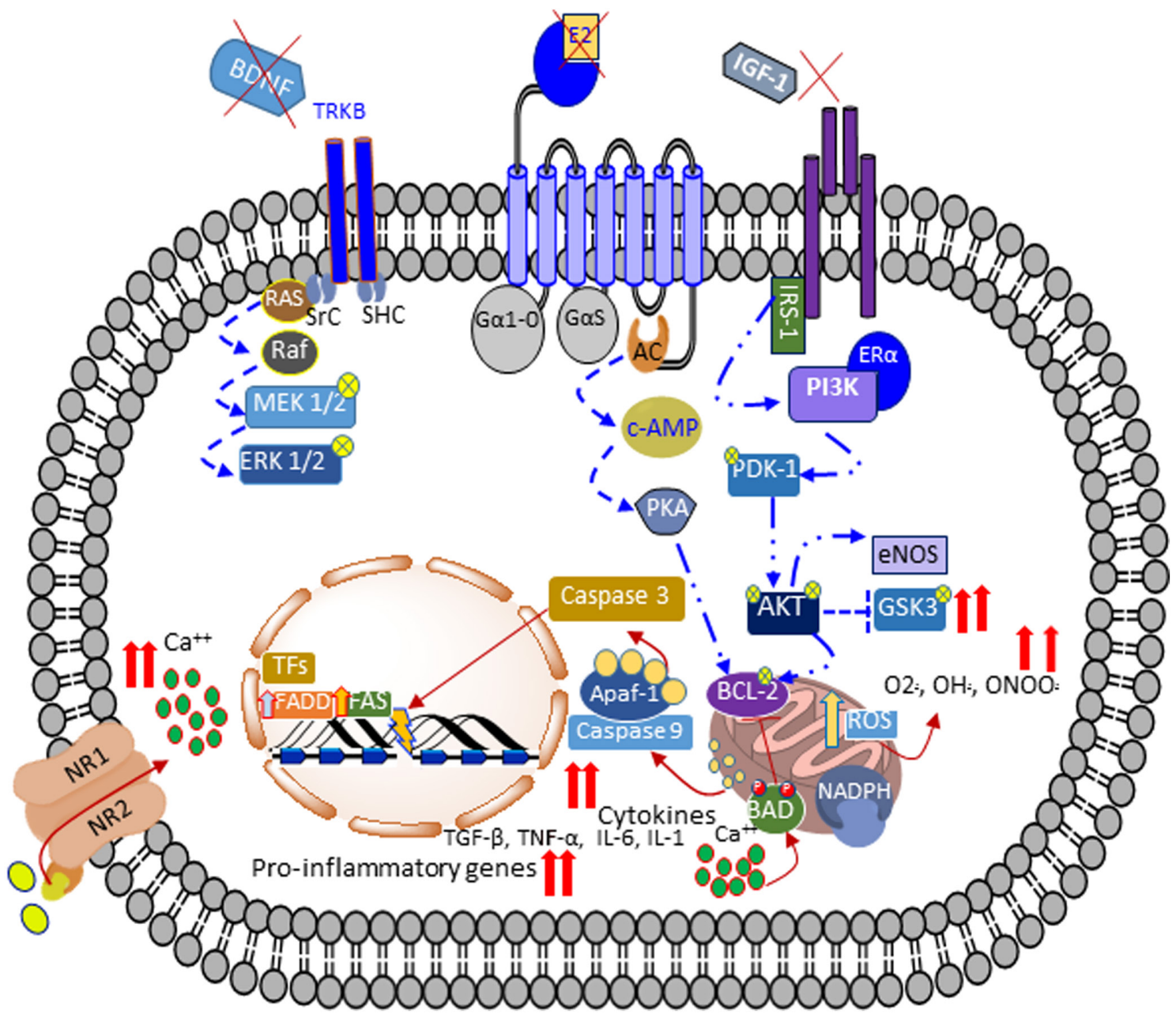

Figure 3

The ischemic cascade may have effect on diverse molecules that participate in neuronal function. The ischemia impedes the supply of several nutrients to neurons, among them hormones and neurotrophins. Thus, the reduction of IGF1/insulin, E2 or neurotrophins, such as BDNF will reduce the signals trough the corresponding receptors, such as IGFR or TrkB). This inactivation/downregulation (represented as dotted lines) will reduce the signals of several pathways such as of PI3K-AKT, generating an imbalance survival/apoptosis. Consequently, dephosphorylation and inactivation of the protein such as, anti-apoptotic BCL-2 or phosphorylation of pro-apoptotic BAD protein, and generation of free radical, and ROS and cytochrome $\mathrm{C}$ release activates caspases 3 and 9, leading to DNA rupture and cell death. In addition, high levels of glutamate lead to an over activation of ionotropic and metabotropic glutamate receptors, with a massive influx of sodium and calcium that cause excitotoxicity and cellular death (red arrows represent the pro-apoptotic elements augmented or over-activated). A full color version of this figure is available at https://doi.org/10.1530/JOE-18-0129. 
response. It is well known that local activation of microglia and astrocytes, known as reactive gliosis, is accompanied by the synthesis and release of several chemokines and cytokines (Dhandapani et al. 2005, Arevalo et al. 2013, Perez-Alvarez \& Wandosell 2016).

Our group and others have reported that post-ischemic estradiol treatment reduces reactive gliosis (Pérez-Álvarez et al. 2012) and attenuates the production of some proinflammatory cytokines after ischemia through activation of ERs (Chiappetta et al. 2007, Suzuki et al. 2007), in parallel with a size reduction of the injured brain region. Since estradiol acts simultaneously on glia and neurons, there is no clear picture of how estradiol impacts the different players involved in ischemic progression (neurons, glia and endothelial cells), nor the implications of this for the pathophysiological events associated with ischemic brain injury (summarized in Fig. 4).

From a molecular point of view, there is a large body of evidence supporting a role for estradiol in the rapid activation of neuronal signaling pathways related to neuronal survival, such as PI3K-AKT-GSK3
(De Butte-Smith et al. 2012, Perez-Alvarez et al. 2012) and ERK/MAPK (Jover-Mengual et al. 2007, Koh 2007), among others (Sawe et al. 2008). In many neurotoxic models, enhancement of these pathways may prevent neuronal death (Pap \& Cooper 1998, Parcellier et al. 2008), though to-date the question about which receptor subtype plays a predominant role in estradiol-mediated neuroprotection from stroke has not been resolved. Experimental evidence in vivo suggests that ER $\beta$ does not play an essential role in neuroprotection after stroke, as administration of an ER $\beta$-selective agonist (diarylpropionitrile, DNP) was not significantly protective in a stroke model (Farr et al. 2007, Connell \& Saleh 2011). Studies in ER $\beta$-knockout mice showed that exogenous administration of estradiol continued to protect the brain against ischemia (Dubal et al. 2001, 2006). In contrast, ER $\beta$ was shown to induce neuroprotection in vitro (using an excitotoxic model of hippocampal neurons) (Zhao \& Brinton 2007), whereas a selective agonist of GPR30 (G-1) has been reported to exert neuroprotection against cerebral ischemia in tMCAO (Zhang et al. 2010). Considering all the contradictory

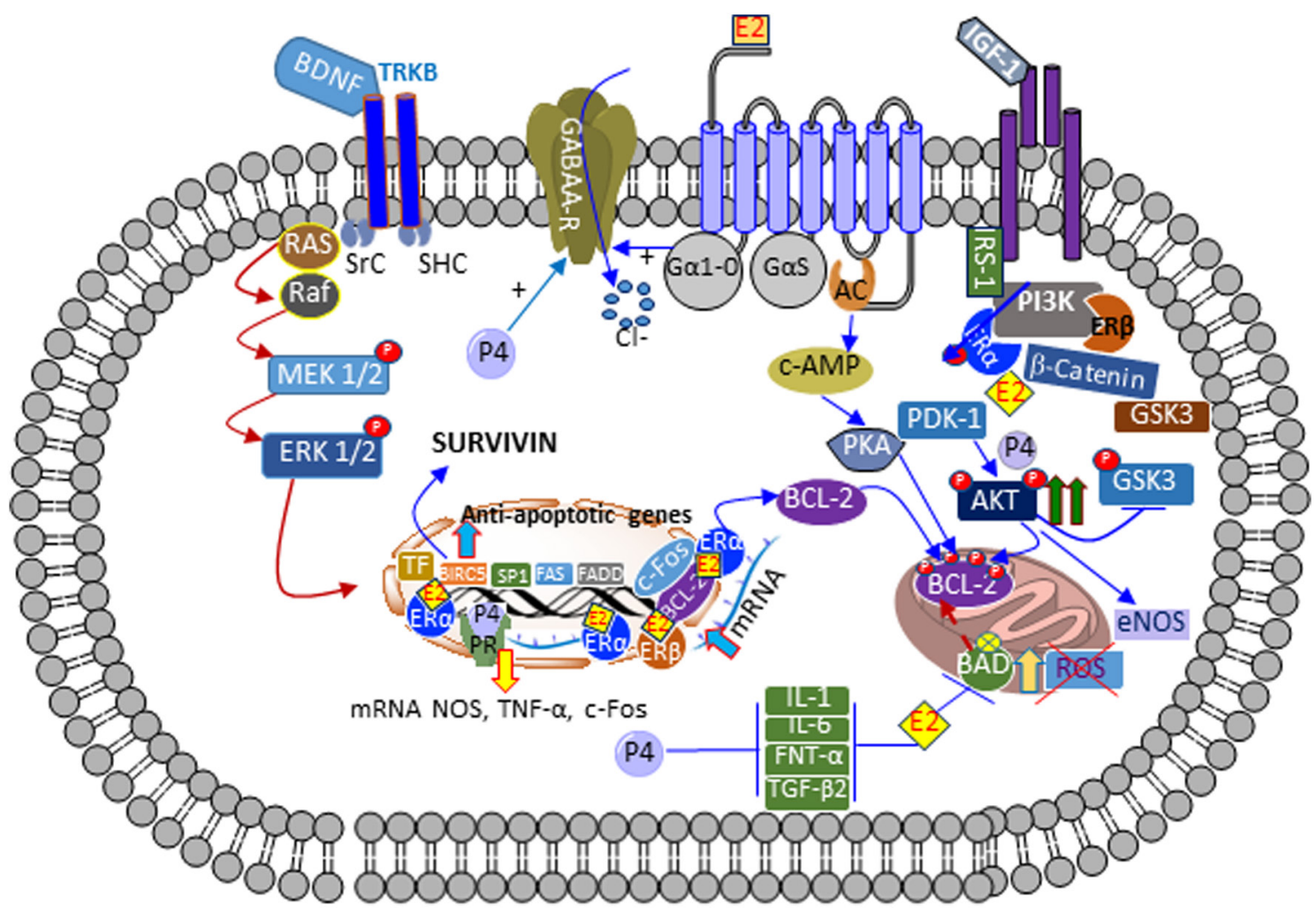

Figure 4

Administration of estradiol and progesterone may reduce ischemic damage. The pharmacological application of E2/P4, in combination, may restart some 'rapid' cell signaling pathways from both estrogen and progesterone, either by membrane receptors or by intracellular counterparts. The activation of E2 and/or P4 signaling may enhancement the PI3K-AKT and MAPK pathway. Besides, both E2 and P4 signaling reduce expression of pro-apoptotic genes and levels of pro-inflammatory cytokines, modulating activity of ionotropic (GABA-A, glutamate) receptors, promoting survival. A full color version of this figure is available at https://doi.org/10.1530/JOE-18-0129. 
results, we can conclude that more work is needed to be able to identify the specific ERs responsible for the neuroprotective action of estradiol.

Information about the neuroprotective effects of progesterone after ischemic damage is not as extensive as for estradiol. It is generally accepted that progesterone attenuates the brain damage induced by ischemia, with some reports showing protective effects in animal models (Roof et al. 1997). Progestogens can act directly in neurons or by modulating glial activation (PerezAlvarez \& Wandosell 2016), and some results indicate that progesterone reduces ischemic damage, acting at different levels of the ischemic cascade. Progesterone ameliorates neuronal excitotoxicity, preventing increase of cytosolic calcium by blocking calcium channels and upregulation of GABA-A receptors (Smith 1991, Limmroth et al. 1996, Shen et al. 2005) and decreases neuronal apoptosis by inhibition of caspase- 3 activity and upregulation of antiapoptotic proteins such as Bcl-2 (Nilsen \& Brinton 2002a, Anderson et al. 2011). Moreover, progesterone may reduce vasogenic and cytotoxic edema.

Progesterone has been shown to be anti-inflammatory, reducing neuroinflammation by different mechanisms (for a review see: Perez-Alvarez \& Wandosell 2016). Progesterone modulates cytokine release, significantly suppressing ischemia-induced upregulation of IL- $1 \beta$ and TGF- $\beta 2$ mRNAs in the ischemic area and also reduces levels of pro-inflammatory cytokine mRNAs (Gibson et al. 2005, Chiappetta et al. 2007). In addition, it reduces peripheral immune cell activation and migration and microglia activation (Roof \& Stein 1992, Drew \& Chavis 2000, Wright et al. 2001, He et al. 2004, Pettus et al. 2005, VanLandingham et al. 2007). All of this anti-inflammatory progesterone activity goes in parallel with a decrease in lesion volume and a reduction of ischemic damage (summarized in Fig. 5).

Experimental data about combined use of estradiol and progesterone for in vivo or in vitro models of stroke are scarce and contradictory (Roof \& Hall 2000), with some pointing to synergistic action and others to nonadditive effects (Dang et al. 2011, Perez-Alvarez et al. 2015). Our studies have shown that the combination of estradiol/progesterone in an in vivo (pMCAO) or in vitro oxygen-glucose deprivation (OGD) model reduced some protective effects of estradiol in the cerebral cortex but not in the hippocampus (Perez-Alvarez et al. 2015), revealing that it is brain region dependent. In fact, estradiol administration after pMCAO greatly reduced reactive gliosis and led to recovery of the PI3K/AKT/GSK3 pathway that had been downregulated by ischemia, whereas the

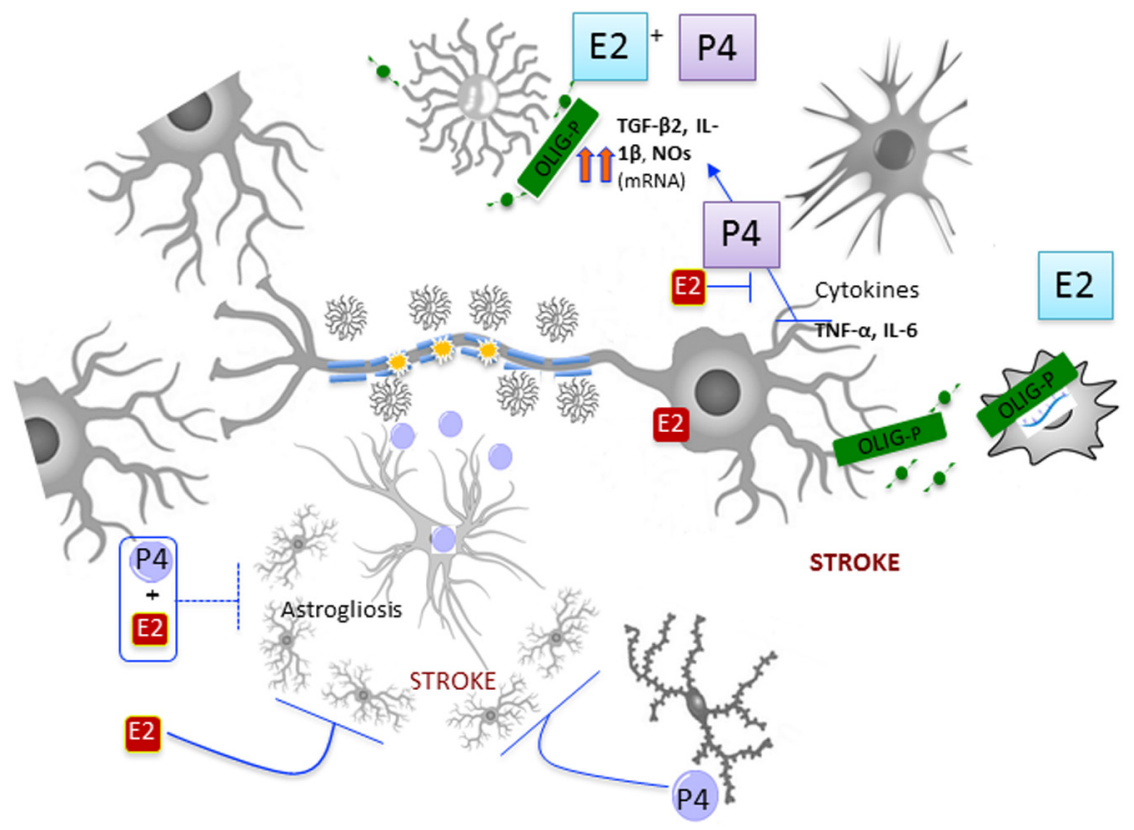

Figure 5

Interaction between neurons, astrocytes and microglial cells during brain injury and the involvement of progesterone and estradiol in regulation and restoration. Stroke induced general activation of glia known as reactive gliosis. These cellular events induce local synthesis of neurosteroids, an endogenous mechanism of neuroprotection. Progesterone can be synthesized in both neurons and quiescent (non-reactive) astrocytes, while E2 is synthesized in both neurons and activated glia.

Pharmacological administration of estradiol and/ or progesterone counteracts the exacerbation of astrocytes and microglia and constrains synthesis and release of pro-inflammatory cytokines (IL-1 $\beta$, TNF- $\alpha$...etc), whereas E2 and P4 association inhibits or reduce this response. Alternatively E2 may improve myelination enhancing proliferation/differentiation of oligodendrocytes which finally will favor axonal remyelination in the neuronal repair process. While the combination with P4 may damper the proliferation and differentiation of oligodendrocyte precursors (OLIG-P) challenging the recovery. It is not yet clear whether co-administration of E2/P4 disrupts the neural repair and neuroprotection that is demonstrated with estradiol alone. A full color version of this figure is available at https://doi.org/10.1530/ JOE-18-0129. 
added presence of progesterone diminished some of these observed beneficial effects. Thus, we have proposed that progesterone may be partially blocking positive effects of estradiol in the brain (Perez-Alvarez et al. 2015).

\section{Conclusions}

Beyond their roles in reproduction, the sexual hormones estradiol and progesterone play a pivotal role in brain functions including development, differentiation and neuroprotection. Estradiol and progesterone show similarities related to their receptors and mechanism of action; both have two main types of receptors that localize to different cellular compartments: nuclear receptors (with a delayed response) and cytoplasmic/membrane receptors (with a fast response). These two groups of receptors trigger different, complex mechanisms that are not fully understood. Estradiol and progesterone, when administered independently, have been described as neuroprotective agents in some neurodegenerative disease models, traumatic disease and even stroke. However, their combined application is controversial, as the effects are sometimes synergistic and other times antagonistic. The discrepancy between different research groups may be explained based on differences in onset of administration, ratio of hormone concentrations, duration of action and brain region studied. Furthermore, details about the interactions between estradiol and progesterone and the differential expression of their receptors in each brain region and are not well understood. According to current evidence, it is possible that they have a close relationship, co-regulating each other's receptors, levels in the brain and cross-interact during intracellular signaling. A deeper understanding of the mechanisms and relationship between both hormones is needed in order to clarify the discrepancies and allow for the design of effective therapies in the future.

\section{Declaration of interest}

The authors declare that there is no conflict of interest that could be perceived as prejudicing the impartiality of this review.

\section{Funding}

This work was supported by a grant from the Centro de Investigacion Biomédica en Red sobre Enfermedades Neurodegenerativas (CIBERNED, an initiative of the ISCIII) and CIBERNED-Proyectos Colaborativos-(PI2016/01) and by a grant from the 'Plan Nacional' of 'Proyectos I+D+i Retos 2015'
SAF2015-70368-R, as well as by an Institutional grant from the 'Fundación Areces'. In addition, A C was supported by a Postdoctoral Contract from the program: 'FORMACIÓN DE TALENTO HUMANO DE ALTO NIVEL.', from Universidad del Tolima; Ibagué-Colombia and C L C were supported by a fellowship from 'Proyecto de Formación de Talento Humano de Alto Nivel', Universidad del Tolima, Ibagué-Colombia.

\section{References}

Acharya KD, Finkelstein SD, Bless EP, Nettles SA, Mulac-Jericevic B, Conneely OM, Mani SK \& Tetel MJ 2015 Estradiol preferentially induces Progestin Receptor-A (PR-A) over PR-B in cells expressing nuclear receptor coactivators in the female mouse hypothalamus. eNeuro 2 ENEURO.0012-0015.2015. (https://doi.org/10.1523/ ENEURO.0012-15.2015)

Afrazi S \& Esmaeili-Mahani S 2014 Allopregnanolone suppresses diabetesinduced neuropathic pain and motor deficit through inhibition of GABA(A) receptor down-regulation in the spinal cord of diabetic rats. Iranian Journal of Basic Medical Sciences 17 312-317.

Aguirre CC \& Baudry M 2009 Progesterone reverses 17ß-EstradiolMediated neuroprotection and BDNF induction in cultured hippocampal slices. European Journal of Neuroscience 29 447-454. (https://doi.org/10.1111/j.1460-9568.2008.06591.x)

Aguirre C, Jayaraman A, Pike C \& Baudry M 2010 Progesterone inhibits estrogen-mediated neuroprotection against excitotoxicity by down-regulating estrogen receptor- $\beta$. Journal of Neurochemistry 115 1277-1287. (https://doi.org/10.1111/j.1471-4159.2010.07038.x)

Alexander A \& Harvey J 2017 Emerging roles for the novel estrogensensing receptor GPER1 in the CNS. Neuropharmacology 113 652-660. (https://doi.org/10.1016/j.neuropharm.2016.07.003)

Alkayed N, Harukuni I, Kimes A, London E, Traystman R \& Hurn P $1998 a$ Gender-linked brain injury in experimental stroke. Stroke 29 159-165. (https://doi.org/10.1161/01.STR.29.1.159)

Alkayed N, Harukuni I, Kimes A, London E, Traystman R \& Hurn P 1998b Gender-linked brain injury in experimental stroke. Stroke 29 159-165.

Alonso A, Moreno Ma, Ordóñez P, Fernández R, Pérez C, Díaz F, Navarro A, Tolivia J \& González C 2008 Chronic estradiol treatment improves brain homeostasis during aging in female rats. Endocrinology 149 57-72. (https://doi.org/10.1210/en.2007-0627)

Amazit L, Roseau A, Khan JA, Chauchereau A, Tyagi RK, Loosfelt H, Leclerc P, Lombès M \& Guiochon-Mantel A 2011 Ligand-dependent degradation of SRC-1 is pivotal for progesterone receptor transcriptional activity. Molecular Endocrinology 25 394-408. (https:// doi.org/10.1210/me.2010-0458)

Anderson GD, Farin FM, Bammler TK, Beyer RP, Swan AA \& Wilkerson HW 2011 The effect of progesterone dose on gene expression after traumatic brain injury. Journal of Neurotrauma $\mathbf{2 8}$ 1827-1843. (https://doi.org/10.1089/neu.2011.1911)

Arbo BD, Benetti F \& Ribeiro MF 2016 Astrocytes as a target for neuroprotection: modulation by progesterone and dehydroepiandrosterone. Progress in Neurobiology 144 27-47. (https:// doi.org/10.1016/j.pneurobio.2016.03.010)

Arevalo MA, Ruiz-Palmero I, Scerbo MJ, Acaz-Fonseca E, Cambiasso MJ \& Garcia-Segura LM 2012 Molecular mechanisms involved in the regulation of neuritogenesis by estradiol: recent advances. Journal of Steroid Biochemistry and Molecular Biology 131 52-56. (https://doi. org/10.1016/j.jsbmb.2011.09.004)

Arevalo MA, Santos-Galindo M, Acaz-Fonseca E, Azcoitia I \& GarciaSegura LM 2013 Gonadal hormones and the control of reactive gliosis. Hormones and Behavior 63 216-221. (https://doi.org/10.1016/j. yhbeh.2012.02.021)

Aupperlee MD \& Haslam SZ 2007 Differential hormonal regulation and function of progesterone receptor isoforms in normal adult http://joe.endocrinology-journals.org

https://doi.org/10.1530/JOE-18-0129 (c) 2018 Society for Endocrinology Published by Bioscientifica Ltd. Printed in Great Britain 
mouse mammary gland. Endocrinology 148 2290-2300. (https://doi. org/10.1210/en.2006-1721)

Azcoitia I, Arevalo M-A, De Nicola AF \& Garcia-Segura LM 2011 Neuroprotective actions of estradiol revisited. Trends in Endocrinology and Metabolism 22 467-473.

Azcoitia I, Arevalo MA \& Garcia-Segura LM 2017 Neural-derived estradiol regulates brain plasticity. Journal of Chemical Neuroanatomy [epub]. (https://doi.org/10.1016/j.jchemneu.2017.04.004)

Baker AE, Brautigam VM \& Watters JJ 2004 Estrogen modulates microglial inflammatory mediator production via interactions with estrogen receptor $\beta$. Endocrinology 145 5021-5032. (https://doi.org/10.1210/ en.2004-0619)

Belelli D, Herd MB, Mitchell EA, Peden DR, Vardy AW, Gentet L \& Lambert JJ 2006 Neuroactive steroids and inhibitory neurotransmission: mechanisms of action and physiological relevance. Neuroscience 138 821-829. (https://doi.org/10.1016/j. neuroscience.2005.07.021)

Bender RA, Zhou L, Wilkars W, Fester L, Lanowski J-S, Paysen D, Konig A \& Rune GM 2010 Roles of 17b-estradiol involve regulation of reelin expression and synaptogenesis in the dentate gyrus. Cerebral Cortex 20 2985-2995. (https://doi.org/10.1093/cercor/bhq047)

Beyer C \& Karolczak M 2000 Estrogenic stimulation of neurite growth in midbrain dopaminergic neurons depends on cAMP/protein kinase A signalling. Journal of Neuroscience Research $\mathbf{5 9} 10$.

Boonyaratanakornkit V, Scott MP, Ribon V, Sherman L, Anderson SM, Maller JL, Miller WT \& Edwards DP 2001 Progesterone receptor contains a proline-rich motif that directly interacts with SH3 domains and activates c-Src family tyrosine kinases. Molecular Cell 8 269-280. (https://doi.org/10.1016/S1097-2765(01)00304-5)

Bourque M, Dluzen DE \& Di Paolo T 2009 Neuroprotective actions of sex steroids in Parkinson's disease. Frontiers in Neuroendocrinology 30 142-157. (https://doi.org/10.1016/j.yfrne.2009.04.014)

Brayman MJ, Julian J, Mulac-Jericevic B, Conneely OM, Edwards DP \& Carson DD 2006 Progesterone receptor isoforms A and B differentially regulate MUC1 expression in uterine epithelial cells. Molecular Endocrinology 20 2278-2291. (https://doi.org/10.1210/me.2005-0343)

Brinton RD, Thompson RF, Foy MR, Baudry M, Wang J, Finch CE, Morgan TE, Pike CJ, Mack WJ, Stanczyk FZ, et al. 2008 Progesterone receptors: form and function in brain. Frontiers in Neuroendocrinology 29 313-339. (https://doi.org/10.1016/j.yfrne.2008.02.001)

Bruce-Keller AJ, Keeling JL, Keller JN, Huang FF, Camondola S \& Mattson MP 2000 Antiinflammatory effects of estrogen on microglial activation. Endocrinology 141 3646-3656. (https://doi.org/10.1210/ endo.141.10.7693)

Cardona-Gomez P, Perez M, Avila J, Garcia-Segura LM \& Wandosell F 2004 Estradiol inhibits GSK3 and regulates interaction of estrogen receptors, GSK3, and beta-catenin in the hippocampus. Molecular and Cellular Neuroscience 25 363-373. (https://doi.org/10.1016/j. mcn.2003.10.008)

Carrer HF \& Aoki A 1982 Ultrastructural changes in the hypothalamic ventromedial nucleus of ovariectomized rats after estrogen treatment. Brain Research 240 221-233. (https://doi.org/10.1016/00068993(82)90218-9)

Carswell HVO, Dominiczak AF, Garcia-Segura LM, Harada N, Hutchison JB \& Macrae IM 2005 Brain aromatase expression after experimental stroke: topography and time course. Journal of Steroid Biochemistry and Molecular Biology 96 89-91.

Conneely OM, Dobson ADW, Tsai M-J, Beattie WG, Toft DO, Huckaby CS, Zarucki T, Schrader WT \& O'Malley BW 1987 Sequence and expression of a functional chicken progesterone receptor. Molecular Endocrinology 1 517-525. (https://doi.org/10.1210/mend-1-8-517)

Connell BJ \& Saleh TM 2011 Differential neuroprotection of selective estrogen receptor agonists against autonomic dysfunction and ischemic cell death in permanent versus reperfusion injury. Advances in Pharmacological Sciences 2011976951.
Cordey M, Gundimeda U, Gopalakrishna R \& Pike CJ 2003 Estrogen activates protein kinase $\mathrm{C}$ in neurons: role in neuroprotection. Journal of Neurochemistry 84 1340-1348. (https://doi.org/10.1046/j.14714159.2003.01631.x)

Coumailleau P, Pellegrini E, Adrio F, Diotel N, Cano-Nicolau J, Nasri A, Vaillant C \& Kah O 2014 Aromatase, estrogen receptors and brain development in fish and amphibians. Biochimica et Biophysica Acta 1849 152-162. (https://doi.org/10.1016/j.bbagrm.2014.07.002)

Chiappetta O, Gliozzi M, Siviglia E, Amantea D, Morrone LA, Berliocchi L, Bagetta G \& Corasaniti MT 2007 Evidence to implicate early modulation of interleukin- $1 \beta$ expression in the neuroprotection afforded by $17 \beta$-estradiol in male rats undergone transient middle cerebral artery occlusion. In International Review of Neurobiology, pp 357-372. Eds MTC Giacinto Bagetta \& AL Stuart. Cambridge, MA, USA: Academic Press.

Dang J, Mitkari B, Kipp M \& Beyer C 2011 Gonadal steroids prevent cell damage and stimulate behavioral recovery after transient middle cerebral artery occlusion in male and female rats. Brain, Behavior, and Immunity 25 715-726. (https://doi.org/10.1016/j.bbi.2011.01.013)

De Butte-Smith M, Zukin RS \& Etgen AM 2012 Effects of global ischemia and estradiol pretreatment on phosphorylation of Akt, CREB and STAT3 in hippocampal CA1 of young and middle-aged female rats. Brain Research 1471 118-128. (https://doi.org/10.1016/j. brainres.2012.06.036)

De Nicola AF, Gonzalez SL, Labombarda F, Deniselle MC, Garay L \& Guennoun R 2006 Progesterone treatment of spinal cord injury: effects on receptors, neurotrophins, and myelination. Journal of Molecular Neuroscience 28 3-15. (https://doi.org/10.1385/JMN:28:1:3)

Deutsch ER, Espinoza TR, Atif F, Woodall E, Kaylor J \& Wright DW 2013 Progesterone's role in neuroprotection, a review of the evidence. Brain Research 1530 82-105. (https://doi.org/10.1016/j. brainres.2013.07.014)

Dhandapani KM, Wade FM, Mahesh VB \& Brann DW 2005 Astrocyte-derived transforming growth factor-\{beta\} mediates the neuroprotective effects of 17 \{beta\}-estradiol: involvement of nonclassical genomic signaling pathways. Endocrinology 146 2749-2759. (https://doi.org/10.1210/en.2005-0014)

Diaz Brinton R 2012 Minireview: translational animal models of human menopause: challenges and emerging opportunities. Endocrinology 153 3571-3578. (https://doi.org/10.1210/en.2012-1340)

Díaz H, Lorenzo A, Carrer HF \& Cáceres A 1992 Time lapse study of neurite growth in hypothalamic dissociated neurons in culture: sex differences and estrogen effects. Journal of Neuroscience Research 33 266-281. (https://doi.org/10.1002/jnr.490330210)

Dirnagl U, Iadecola C \& Moskowitz MA 1999 Pathobiology of ischaemic stroke: an integrated view. Trends in Neurosciences 22 391-397. (https://doi.org/10.1016/S0166-2236(99)01401-0)

Do Rego JL, Seong JY, Burel D, Leprince J, Vaudry D, Luu-The V, Tonon MC, Tsutsui K, Pelletier G \& Vaudry H 2012 Regulation of neurosteroid biosynthesis by neurotransmitters and neuropeptides. Frontiers in Endocrinology 3 4. (https://doi.org/10.3389/ fendo.2012.00004)

Dominguez R \& Micevych P 2010 Estradiol rapidly regulates membrane estrogen receptor $\alpha$ levels in hypothalamic neurons. Journal of Neuroscience 30 12589-12596. (https://doi.org/10.1523/ JNEUROSCI.1038-10.2010)

Drew PD \& Chavis JA 2000 Female sex steroids: effects upon microglial cell activation. Journal of Neuroimmunology 111 77-85. (https://doi. org/10.1016/S0165-5728(00)00386-6)

Dubal DB, Kashon ML, Pettigrew LC, Ren JM, Finklestein SP, Rau SW \& Wise PM 1998 Estradiol protects against ischemic injury. Journal of Cerebral Blood Flow and Metabolism 18 1253-1258. (https://doi. org/10.3389/fendo.2012.00004)

Dubal DB, Zhu H, Yu J, Rau SW, Shughrue PJ, Merchenthaler I, Kindy MS \& Wise PM 2001 Estrogen receptor alpha, not beta, is a critical link
(C) 2018 Society for Endocrinology Published by Bioscientifica Ltd. Printed in Great Britain 
in estradiol-mediated protection against brain injury. PNAS $\mathbf{9 8}$ 1952-1957. (https://doi.org/10.1073/pnas.041483198)

Dubal DB, Rau SW, Shughrue PJ, Zhu H, Yu J, Cashion AB, Suzuki S, Gerhold LM, Bottner MB, Dubal SB, et al. 2006 Differential modulation of estrogen receptors (ERs) in ischemic brain injury: a role for ERalpha in estradiol-mediated protection against delayed cell death. Endocrinology 147 3076-3084. (https://doi.org/10.1210/ en.2005-1177)

Engler-Chiurazzi EB, Singh M \& Simpkins JW 2016 Reprint of: from the 90's to now: a brief historical perspective on more than two decades of estrogen neuroprotection. Brain Research 1645 79-82. (https://doi. org/10.1016/j.brainres.2016.06.016)

Farr TD, Carswell HV, Gsell W \& Macrae IM 2007 Estrogen receptor beta agonist diarylpropiolnitrile (DPN) does not mediate neuroprotection in a rat model of permanent focal ischemia. Brain Research 1185 275-282. (https://doi.org/10.1016/i.brainres.2007.09.009)

Fester L, Zhou L, Bütow A, Huber C, von Lossow R, Prange-Kiel J, Jarry H \& Rune GM 2009 Cholesterol-promoted synaptogenesis requires the conversion of cholesterol to estradiol in the hippocampus. Hippocampus 19 692-705. (https://doi.org/10.1002/hipo.20548)

Filardo EJ \& Thomas P 2005 GPR30: a seven-transmembrane-spanning estrogen receptor that triggers EGF release. Trends in Endocrinology and Metabolism 16 362-367. (https://doi.org/10.1016/j.tem.2005.08.005)

Filardo E, Quinn J, Pang Y, Graeber C, Shaw S, Dong J \& Thomas P 2007 Activation of the novel estrogen receptor $\mathrm{G}$ protein-coupled receptor 30 (GPR30) at the plasma membrane. Endocrinology 148 3236-3245. (https://doi.org/10.1210/en.2006-1605)

Forlano PM, Deitcher DL, Myers DA \& Bass AH 2001 Anatomical distribution and cellular basis for high levels of aromatase activity in the brain of teleost fish: aromatase enzyme and mRNA expression identify glia as source. Journal of Neuroscience 21 8943-8955.

Foy MR, Akopian G \& Thompson RF 2008 Progesterone regulation of synaptic transmission and plasticity in rodent hippocampus. Learning and Memory 15 820-822. (https://doi.org/10.1101/lm.1124708)

Garay L, Gonzalez Deniselle MC, Gierman L, Meyer M, Lima A, Roig P \& De Nicola AF 2008 Steroid protection in the experimental autoimmune encephalomyelitis model of multiple sclerosis. Neuroimmunomodulation 15 76-83. (https://doi. org/10.1159/000135627)

Garcia-Segura LM, Naftolin F, Hutchison JB, Azcoitia I \& Chowen JA 1999 Role of astroglia in estrogen regulation of synaptic plasticity and brain repair. Journal of Neurobiology 40 574-584. (https://doi.org/10.1002/ (SICI)1097-4695(19990915)40:4<574::AID-NEU12>3.0.CO;2-8)

Garcia-Segura LM, Arévalo M-A \& Azcoitia I 2010 Interactions of estradiol and insulin-like growth factor-I signalling in the nervous system: new advances. In Progress in Brain Research, ch 14, pp 251-272. Ed M Luciano. New York, NY, USA: Elsevier.

Ghoumari AM, Baulieu EE \& Schumacher M 2005 Progesterone increases oligodendroglial cell proliferation in rat cerebellar slice cultures. Neuroscience 135 47-58. (https://doi.org/10.1016/j. neuroscience.2005.05.023)

Giachino C, Galbiati M, Fasolo A, Peretto P \& Melcangi R 2003 Neurogenesis in the subependymal layer of the adult rat. Annals of the New York Academy of Sciences 1007 335-339. (https://doi.org/10.1196/ annals.1286.032)

Gibson CL, Constantin D, Prior MJW, Bath PMW \& Murphy SP 2005 Progesterone suppresses the inflammatory responseand nitric oxide synthase-2 expression following cerebral ischemia. Experimental Neurology 193 522-530. (https://doi.org/10.1016/j. expneurol.2005.01.009)

Gruber CJ, Tschugguel W, Schneeberger C \& Huber JC 2002 Production and actions of estrogens. New England Journal of Medicine 346 340-352. (https://doi.org/10.1056/NEJMra000471)

Guennoun R, Meffre D, Labombarda F, Gonzalez SL, Deniselle MCG, Stein DG, De Nicola AF \& Schumacher M 2008 The membraneassociated progesterone-binding protein 25-Dx: expression, cellular localization and up-regulation after brain and spinal cord injuries. Brain Research Reviews 57 493-505. (https://doi.org/10.1016/j. brainresrev.2007.05.009)

Guennoun R, Labombarda F, Gonzalez Deniselle MC, Liere P, De Nicola AF \& Schumacher M 2015 Progesterone and allopregnanolone in the central nervous system: response to injury and implication for neuroprotection. Journal of Steroid Biochemistry and Molecular Biology 146 48-61. (https://doi.org/10.1016/j.jsbmb.2014.09.001)

He J, Evans CO, Hoffman SW, Oyesiku NM \& Stein DG 2004 Progesterone and allopregnanolone reduce inflammatory cytokines after traumatic brain injury. Experimental Neurology 189 404-412. (https://doi. org/10.1016/j.expneurol.2004.06.008)

Hewitt SC, Li Y, Li L \& Korach KS 2010 Estrogen-mediated regulation of Igf1 transcription and uterine growth involves direct binding of estrogen receptor alpha to estrogen-responsive elements. Journal of Biological Chemistry 285 2676-2685. (https://doi.org/10.1074/jbc. M109.043471)

Hilton GD, Nunez JL, Bambrick L, Thompson SM \& McCarthy MM 2006 Glutamate-mediated excitotoxicity in neonatal hippocampal neurons is mediated by mGluR-induced release of $\mathrm{Ca}++$ from intracellular stores and is prevented by estradiol. European Journal of Neuroscience 24 3008-3016. (https://doi.org/10.1111/j.1460-9568.2006.05189.x)

Hirata S, Shoda T, Kato J \& Hoshi K 2002 The novel isoform of the estrogen receptor-Î \pm cDNA (ERÎ \pm isoform S CDNA) in the human testis. Journal of Steroid Biochemistry and Molecular Biology 80 299-305. (https://doi.org/10.1016/S0960-0760(02)00020-1)

Hoffman GE, Merchenthaler I \& Zup SL 2006 Neuroprotection by ovarian hormones in animal models of neurological disease. Endocrine 2914.

Honda K, Sawada H, Kihara T, Urushitani M, Nakamizo T, Akaike A \& Shimohama S 2000 Phosphatidylinositol 3-kinase mediates neuroprotection by estrogen in cultured cortical neurons. Journal of Neuroscience Research 60 321-327. (https://doi.org/10.1002/ (SICI) 1097-4547(20000501)60:3<321::AID-JNR6>3.0.CO;2-T)

Hosie AM, Wilkins ME, da Silva HMA \& Smart TG 2006 Endogenous neurosteroids regulate GABAA receptors through two discrete transmembrane sites. Nature $\mathbf{4 4 4} 486-489$. (https://doi.org/10.1038/ nature05324)

Hu R, Cai WQ, Wu XG \& Yang Z 2007 Astrocyte-derived estrogen enhances synapse formation and synaptic transmission between cultured neonatal rat cortical neurons. Neuroscience 144 1229-1240. (https://doi.org/10.1016/j.neuroscience.2006.09.056)

Hu P, Liu J, Yasrebi A, Gotthardt JD, Bello NT, Pang ZP \& Roepke TA 2016 Gq protein-coupled membrane-initiated estrogen signaling rapidly excites corticotropin-releasing hormone neurons in the hypothalamic paraventricular nucleus in female mice. Endocrinology 157 3604-3620. (https://doi.org/10.1210/en.2016-1191)

Huang C-T, Chen S-H, Lue J-H, Chang C-F, Wen W-H \& Tsai Y-J 2016 Neurosteroid allopregnanolone suppresses median nerve injuryinduced mechanical hypersensitivity and glial extracellular signalregulated kinase activation through $\gamma$-aminobutyric acid type a receptor modulation in the rat cuneate nucleus. Anesthesiology $\mathbf{1 2 5}$ 1202-1218. (https://doi.org/10.1097/ALN.0000000000001360)

Hübner S, Reich B \& Heckmann M 2015 Role of sex steroids and their receptors in human preterm infants: impacts on future treatment strategies for cerebral development. Biochemical Pharmacology 98 556-563. (https://doi.org/10.1016/j.bcp.2015.08.093)

Inagaki T \& Etgen AM 2013 Neuroprotective action of acute estrogens: animal models of brain ischemia and clinical implications. Steroids $\mathbf{7 8}$ 597-606. (https://doi.org/10.1016/j.steroids.2012.12.015)

Irwin RW, Yao J, Hamilton RT, Cadenas E, Brinton RD \& Nilsen J 2008 Progesterone and estrogen regulate oxidative metabolism in brain mitochondria. Endocrinology 149 3167-3175. (https://doi. org/10.1210/en.2007-1227)

Jickling GC \& Sharp FR 2015 Improving the translation of animal ischemic stroke studies to humans. Metabolic Brain Disease 30 461-467. (https://doi.org/10.1007/s11011-014-9499-2) 
Jover-Mengual T, Zukin RS \& Etgen AM 2007 MAPK signaling is critical to estradiol protection of CA1 neurons in global ischemia. Endocrinology 148 1131-1143. (https://doi.org/10.1210/en.2006-1137)

Jung-Testas I, Do Thi A, Koenig H, Désarnaud F, Shazand K, Schumacher M \& Baulieu EE 1999 Progesterone as a neurosteroid: synthesis and actions in rat glial cells. Journal of Steroid Biochemistry and Molecular Biology 69 97-107. (https://doi.org/10.1016/S09600760(98)00149-6)

Kastner P, Krust A, Turcotte B, Stropp U, Tora L, Gronemeyer H \& Chambon P 1990 Two distinct estrogen-regulated promoters generate transcripts encoding the two functionally different human progesterone receptor forms A and B. EMBO Journal 9 1603-1614

Koh PO 2007 Estradiol prevents the injury-induced decrease of 90 ribosomal S6 kinase (p90RSK) and Bad phosphorylation. Neuroscience Letters 412 68-72. (https://doi.org/10.1016/j.neulet.2006.10.060)

Konings GFJ, Reynaert NL, Delvoux B, Verhamme FM, Bracke KR, Brusselle GG, Romano A \& Vernooy JHJ 2017 Increased levels of enzymes involved in local estradiol synthesis in chronic obstructive pulmonary disease. Molecular and Cellular Endocrinology 443 23-31. (https://doi.org/10.1016/j.mce.2016.12.001)

Korol DL \& Pisani SL 2015 Estrogens and cognition: friends or foes?: an evaluation of the opposing effects of estrogens on learning and memory. Hormones and Behavior 74 105-115. (https://doi. org/10.1016/j.yhbeh.2015.06.017)

Kretz O, Fester L, Wehrenberg U, Zhou L, Brauckmann S, Zhao S, Prange-Kiel J, Naumann T, Jarry H, Frotscher M, et al. 2004 Hippocampal synapses depend on hippocampal estrogen synthesis. Journal of Neuroscience 24 5913-5921. (https://doi.org/10.1523/ JNEUROSCI.5186-03.2004)

Labombarda F, Ghoumari AM, Liere P, De Nicola AF, Schumacher M \& Guennoun R 2013 Neuroprotection by steroids after neurotrauma in organotypic spinal cord cultures: a key role for progesterone receptors and steroidal modulators of GABAA receptors. Neuropharmacology 71 46-55. (https://doi.org/10.1016/j. neuropharm.2013.03.010)

Lee E, Sidoryk-Wêgrzynowicz M, Wang N, Webb A, Son D-S, Lee K \& Aschner M 2012 GPR30 regulates glutamate transporter GLT-1 expression in rat primary astrocytes. Journal of Biological Chemistry 287 26817-26828. (https://doi.org/10.1074/jbc.M112.341867)

Lenz KM \& McCarthy MM 2010 Organized for sex - steroid hormones and the developing hypothalamus. European Journal of Neuroscience 32 2096-2104. (https://doi.org/10.1111/j.1460-9568.2010.07511.x)

Liao S, Chen W, Kuo J \& Chen C 2001 Association of serum estrogen level and ischemic neuroprotection in female rats. Neuroscience Letters 297 159-162. (https://doi.org/10.1016/S0304-3940(00)01704-3)

Limmroth V, Lee WS \& Moskowitz MA 1996 GABAA-receptor-mediated effects of progesterone, its ring-A-reduced metabolites and synthetic neuroactive steroids on neurogenic oedema in the rat meninges. British Journal of Pharmacology 117 99-104. (https://doi. org/10.1111/j.1476-5381.1996.tb15160.x)

Lorenz L, Dang J, Misiak M, Tameh Abolfazl A, Beyer C \& Kipp M 2009 Combined $17 \beta$-oestradiol and progesterone treatment prevents neuronal cell injury in cortical but not midbrain neurones or neuroblastoma cells. Journal of Neuroendocrinology 21 841-849. (https://doi.org/10.1111/j.1365-2826.2009.01903.x)

Luchetti S, Bossers K, Van de Bilt S, Agrapart V, Morales RR, Frajese GV \& Swaab DF 2011 Neurosteroid biosynthetic pathways changes in prefrontal cortex in Alzheimer's disease. Neurobiology of Aging 32 1964-1976. (https://doi.org/10.1016/j.neurobiolaging.2009.12.014)

Luquin S, Naftolin F \& Garcia-Segura LM 1993 Natural fluctuation and gonadal hormone regulation of astrocyte immunoreactivity in dentate gyrus. Journal of Neurobiology 24 913-924. (https://doi. org/10.1002/neu.480240705)

Maki PM \& Henderson VW 2012 Hormone therapy, dementia, and cognition: the Women's Health Initiative 10 years on. Climacteric $\mathbf{1 5}$ 256-262. (https://doi.org/10.3109/13697137.2012.660613)
Mani S \& Oyola M 2012 Progesterone signaling mechanisms in brain and behavior. Frontiers in Endocrinology 37.

Mann V, Huber C, Kogianni G, Collins F \& Noble B 2007 The antioxidant effect of estrogen and selective estrogen receptor modulators in the inhibition of osteocyte apoptosis in vitro. Bone $\mathbf{4 0}$ 674-684. (https:// doi.org/10.1016/j.bone.2006.10.014)

McCullough LD, Blizzard K, Simpson ER, Oz OK \& Hurn PD 2003 Aromatase cytochrome $\mathrm{P} 450$ and extragonadal estrogen play a role in ischemic neuroprotection. Journal of Neuroscience 23 8701-8705.

Medway C, Combarros O, Cortina-Borja M, Butler HT, IbrahimVerbaas CA, de Bruijn RF, Koudstaal PJ, van Duijn CM, Ikram MA, Mateo I, et al. 2014 The sex-specific associations of the aromatase gene with Alzheimer's disease and its interaction with IL10 in the Epistasis Project. European Journal of Human Genetics 22 216-220. (https://doi.org/10.1038/ejhg.2013.116)

Meffre D, Delespierre B, Gouézou M, Leclerc P, Vinson GP, Schumacher M, Stein DG \& Guennoun R 2005 The membraneassociated progesterone-binding protein 25 -Dx is expressed in brain regions involved in water homeostasis and is up-regulated after traumatic brain injury. Journal of Neurochemistry 93 1314-1326. (https://doi.org/10.1111/j.1471-4159.2005.03127.x)

Meffre D, Labombarda F, Delesepierre B, Chastre A, De Nicola AF, Stein DG, Schumacher M \& Guennoun R 2013 Distribution of membrane progesterone receptor alpha in the male mouse and rat brain and its regulation after traumatic brain injury. Neuroscience 231 111-124. (https://doi.org/10.1016/j.neuroscience.2012.11.039)

Melcangi RC, Giatti S, Calabrese D, Pesaresi M, Cermenati G, Mitro N, Viviani B, Garcia-Segura LM \& Caruso D 2014 Levels and actions of progesterone and its metabolites in the nervous system during physiological and pathological conditions. Progress in Neurobiology 113 56-69. (https://doi.org/10.1016/j.pneurobio.2013.07.006)

Melcangi RC, Giatti S \& Garcia-Segura LM 2016 Levels and actions of neuroactive steroids in the nervous system under physiological and pathological conditions: sex-specific features. Neuroscience and Biobehavioral Reviews 67 25-40. (https://doi.org/10.1016/j. neubiorev.2015.09.023)

Mendez P, Azcoitia I \& Garcia-Segura LM 2003 Estrogen receptor alpha forms estrogen-dependent multimolecular complexes with insulinlike growth factor receptor and phosphatidylinositol 3-kinase in the adult rat brain. Molecular Brain Research 112 170-176. (https://doi. org/10.1016/S0169-328X(03)00088-3)

Merchenthaler I, Dellovade TL \& Shughrue PJ 2003 Neuroprotection by estrogen in animal models of global and focal ischemia. Annals of the New York Academy of Sciences 1007 89-100. (https://doi.org/10.1196/ annals.1286.009)

Meyer C, Schmid R, Scriba PC \& Wehling M 1996 Purification and partial sequencing of high-affinity progesterone-binding site(s) from porcine liver membranes. European Journal of Biochemistry 239 726-731. (https://doi.org/10.1111/j.1432-1033.1996.0726u.x)

Migliaccio A, Piccolo D, Castoria G, Di Domenico M, Bilancio A, Lombardi M, Gong W, Beato M \& Auricchio F 1998 Activation of the Src/p21ras/Erk pathway by progesterone receptor via cross-talk with estrogen receptor. EMBO Journal 17 2008-2018. (https://doi. org/10.1093/emboj/17.7.2008)

Mott NN \& Pak TR 2013 Estrogen signaling and the aging brain: context-dependent considerations for postmenopausal hormone therapy. ISRN Endocrinology 2013 article ID 814690. (https://doi. org/10.1155/2013/814690)

Mozaffarian D, Benjamin EJ, Go AS, Arnett DK, Blaha MJ, Cushman M, Das SR, de Ferranti S, Després J-P, Fullerton HJ, et al. 2016 Executive summary: heart disease and stroke statistics -2016 update. A report from the American Heart Association. Circulation 131 e29-e322. (https://doi.org/10.1161/CIR.0000000000000152)

Nag S \& Mokha SS 2014 Activation of a Gq-coupled membrane estrogen receptor rapidly attenuates $\alpha 2$-adrenoceptor-induced antinociception via an ERK I/II-dependent, non-genomic mechanism in the 
female rat. Neuroscience 267 122-134. (https://doi.org/10.1016/j. neuroscience.2014.02.040)

Nilsen J \& Brinton RD 2002a Impact of progestins on estradiol potentiation of the glutamate calcium response. Neuroreport 13 825-830. (https://doi.org/10.1097/00001756-200205070-00018)

Nilsen J \& Brinton RD $2002 b$ Impact of progestins on estrogen-induced neuroprotection: synergy by progesterone and 19-norprogesterone and antagonism by medroxyprogesterone acetate. Endocrinology 143 205-212. (https://doi.org/10.1210/endo.143.1.8582)

Noorbakhsh F, Baker GB \& Power C 2014 Allopregnanolone and neuroinflammation: a focus on multiple sclerosis. Frontiers in Cellular Neuroscience 8 134. (https://doi.org/10.3389/fncel.2014.00134)

Pajović SB \& Saičić ZS 2008 Modulation of antioxidant enzyme activities by sexual steroid hormones. Physiological Research 57 801-811.

Pang Y, Dong J \& Thomas P 2013 Characterization, neurosteroid binding and brain distribution of human membrane progesterone receptors

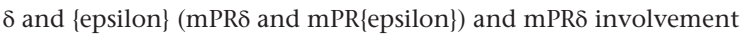
in neurosteroid inhibition of apoptosis. Endocrinology 154 283-295. (https://doi.org/10.1210/en.2012-1772)

Pap M \& Cooper GM 1998 Role of glycogen synthase kinase-3 in the phosphatidylinositol 3-Kinase/Akt cell survival pathway. Journal of Biological Chemistry 273 19929-19932. (https://doi.org/10.1074/ jbc.273.32.19929)

Parcellier A, Tintignac LA, Zhuravleva E \& Hemmings BA 2008 PKB and the mitochondria: AKTing on apoptosis. Cell Signaling 20 21-30. (https://doi.org/10.1016/j.cellsig.2007.07.010)

Park YM, Erickson C, Bessesen D, Van Pelt RE \& Cox-York K 2017 Ageand menopause-related differences in subcutaneous adipose tissue estrogen receptor mRNA expression. Steroids 121 17-21. (https://doi. org/10.1016/j.steroids.2017.03.001)

Pedersen AL, Nelson LH \& Saldanha CJ 2016 Centrally synthesized estradiol is a potent anti-inflammatory in the injured Zebra finch brain. Endocrinology 157 2041-2051. (https://doi.org/10.1210/ en.2015-1991)

Pelletier G 2010 Steroidogenic enzymes in the brain: morphological aspects. Progress in Brain Research 181 193-207. (https://doi. org/10.1016/S0079-6123(08)81011-4)

Pérez-Alvarez MJ \& Wandosell F 2013 Estradiol in CNS: role in neurodegeneration. In Estradiol: Synthesis, Health Effects and Drug Interaction, 1st ed., p 39. Eds R Palmeri \& S Grimaudo. New York, NY, USA: Nova Science Publishers.

Perez-Alvarez MJ \& Wandosell F 2016 Stroke and neuroinflamation: role of sexual hormones. Current Pharmaceutical Design 22 1334-1349. (https://doi.org/10.2174/138161282210160304112834)

Pérez-Álvarez MJ, Maza MDC, Anton M, Ordoñez L \& Wandosell F 2012 Post-ischemic estradiol treatment reduced glial response and triggers distinct cortical and hippocampal signaling in a rat model of cerebral ischemia. Journal of Neuroinflammation 9157.

Perez-Alvarez MJ, Mateos L, Alonso A \& Wandosell F 2015 Estradiol and progesterone administration after PMCAO stimulates the neurological recovery and reduces the detrimental effect of ischemia mainly in hippocampus. Molecular Neurobiology 52 1690-1703. (https://doi. org/10.1007/s12035-014-8963-7)

Peterson RS, Saldanha CJ \& Schlinger BA 2001 Rapid upregulation of aromatase mRNA and protein following neural injury in the zebra finch (Taeniopygia guttata). Journal of Neuroendocrinology 13 317-323. (https://doi.org/10.1046/j.1365-2826.2001.00647.x)

Pettersson K, Grandien K, Kuiper GGJM \& Gustafsson J-Ak 1997 Mouse estrogen receptor $\beta$ forms estrogen response element-binding heterodimers with estrogen receptor $\alpha$. Molecular Endocrinology 11 1486-1496.

Pettus EH, Wright DW, Stein DG \& Hoffman SW 2005 Progesterone treatment inhibits the inflammatory agents that accompany traumatic brain injury. Brain Research 1049 112-119. (https://doi. org/10.1016/j.brainres.2005.05.004)
Prossnitz ER \& Barton M 2011 The G-protein-coupled estrogen receptor GPER in health and disease. Nature Reviews Endocrinology 7 715-726. (https://doi.org/10.1038/nrendo.2011.122)

Prossnitz ER, Arterburn JB \& Sklar LA 2007 GPR30: a G protein-coupled receptor for estrogen. Molecular and Cellular Endocrinology 265-266 138-142. (https://doi.org/10.1016/j.mce.2006.12.010)

Prossnitz ER, Arterburn JB, Smith HO, Oprea TI, Sklar LA \& Hathaway HJ 2008 Estrogen signaling through the transmembrane G proteincoupled receptor GPR30. Annual Review of Physiology 70 165-190. (https://doi.org/10.1146/annurev.physiol.70.113006.100518)

Qiu J, Rønnekleiv OK \& Kelly MJ 2008 Modulation of hypothalamic neuronal activity through a novel G-protein-coupled estrogen membrane receptor. Steroids 73 985-991. (https://doi.org/10.1016/j. steroids.2007.11.008)

Raz L, Khan MM, Mahesh VB, Vadlamudi RK \& Brann DW 2008 Rapid estrogen signaling in the brain. Neurosignals 16 140-153. (https://doi. org/10.1159/000111559)

Revankar CM, Cimino DF, Sklar LA, Arterburn JB \& Prossnitz ER 2005 A transmembrane intracellular estrogen receptor mediates rapid cell signaling. Science 307 1625-1630. (https://doi.org/10.1126/ science.1106943)

Roche SL, Wyse-Jackson AC, Gómez-Vicente V, Lax P, Ruiz-Lopez AM, Byrne AM, Cuenca NS \& Cotter TG 2016 Progesterone attenuates microglial-driven retinal degeneration and stimulates protective fractalkine-CX3CR1 signaling. PLoS ONE 11 e0165197. (https://doi. org/10.1371/journal.pone.0165197)

Roof RL \& Stein DG 1992 Progesterone treatment attenuates brain edema following contusion injury in male and female rats. Restorative Neurology and Neuroscience 4 425-427.

Roof RL \& Hall ED 2000 Gender differences in acute CNS trauma and stroke: neuroprotective effects of estrogen and progesterone. Journal of Neurotrauma 17 367-388. (https://doi.org/10.1089/neu.2000.17.367)

Roof RL, Hoffman SW \& Stein DG 1997 Progesterone protects against lipid peroxidation following traumatic brain injury in rats. Molecular and Chemical Neuropathology 31 1-11. (https://doi.org/10.1007/ BF02815156)

Roselli CF 2007 Brain aromatase: roles in reproduction and neuroprotection. Journal of Steroid Biochemistry and Molecular Biology 106 143-150. (https://doi.org/10.1016/j.jsbmb.2007.05.014)

Rusa R, Alkayed NJ, Crain BJ, Traystman RJ, Kimes AS, London ED, Klaus JA \& Hurn PD 1999 17beta-estradiol reduces stroke injury in estrogen-deficient female animals. Stroke 30 1665-1670. (https://doi. org/10.1161/01.STR.30.8.1665)

Sawada M, Alkayed NJ, Goto S, Crain BJ, Traystman RJ, Shaivitz A, Nelson RJ \& Hurn PD 2000 Estrogen receptor antagonist ICI182,780 exacerbates ischemic injury in female mouse. Journal of Cerebral Blood Flow and Metabolism 20 112-118. (https://doi.org/10.1097/00004647200001000-00015)

Sawe N, Steinberg G \& Zhao H 2008 Dual roles of the MAPK/ERK1/2 cell signaling pathway after stroke. Journal of Neuroscience Research $\mathbf{8 6}$ 1659-1669. (https://doi.org/10.1002/jnr.21604)

Sayeed I \& Stein DG 2009 Progesterone as a neuroprotective factor in traumatic and ischemic brain injury. Progress in Brain Research $\mathbf{1 7 5}$ 219-237. (https://doi.org/10.1016/S0079-6123(09)17515-5)

Scott E, Zhang Q-G, Wang R, Vadlamudi R \& Brann D 2012 Estrogen neuroprotection and the critical period hypothesis. Frontiers in Neuroendocrinology 33 85-104. (https://doi.org/10.1016/j. yfrne.2011.10.001)

Schreihofer DA \& Ma Y 2013 Estrogen receptors and ischemic neuroprotection: who, what, where and when? Brain Research 1514 107-122. (https://doi.org/10.1016/j.brainres.2013.02.051)

Schumacher M, Mattern C, Ghoumari A, Oudinet JP, Liere P, Labombarda F, Sitruk-Ware R, De Nicola AF \& Guennoun R 2014 Revisiting the roles of progesterone and allopregnanolone in the nervous system: resurgence of the progesterone receptors.
(C) 2018 Society for Endocrinology Published by Bioscientifica Ltd. Printed in Great Britain 
Progress in Neurobiology 113 6-39. (https://doi.org/10.1016/j. pneurobio.2013.09.004)

Schumacher M, Denier C, Oudinet J-P, Adams D \& Guennoun R 2016 Progesterone neuroprotection: the background of clinical trial failure. Journal of Steroid Biochemistry and Molecular Biology 160 53-66. (https://doi.org/10.1016/j.jsbmb.2015.11.010)

Shao H, Breitner JC, Whitmer RA, Wang J, Hayden K, Wengreen H, Corcoran C, Tschanz J, Norton M, Munger R, et al. 2012 Hormone therapy and Alzheimer disease dementia: new findings from the Cache County Study. Neurology 79 1846-1852. (https://doi. org/10.1212/WNL.0b013e318271f823)

Shen H, Gong QH, Yuan M \& Smith SS 2005 Short-term steroid treatment increases delta GABAA receptor subunit expression in rat CA1 hippocampus: pharmacological and behavioral effects. Neuropharmacology 49 573-586. (https://doi.org/10.1016/j. neuropharm.2005.04.026)

Shughrue P, Scrimo P, Lane M, Askew R \& Merchenthaler I 1997 The distribution of estrogen receptor- $\beta$ mRNA in forebrain regions of the estrogen receptor- $\alpha$ knockout mouse. Endocrinology 138 5649-5652. (https://doi.org/10.1210/endo.138.12.5712)

Simpkins JW, Wen Y, Perez E, Yang S \& Wang X 2005 Role of nonfeminizing estrogens in brain protection from cerebral ischemia: an animal model of Alzheimer's disease neuropathology. Annals of the New York Academy of Sciences 1052 233-242. (https://doi.org/10.1196/ annals.1347.019)

Sinchak K \& Wagner EJ 2012 Estradiol signaling in the regulation of reproduction and energy balance. Frontiers in Neuroendocrinology 33 342-363. (https://doi.org/10.1016/j.yfrne.2012.08.004)

Singh M, Setalo G Jr, Guan X, Warren M \& Toran-Allerand CD 1999 Estrogen-induced activation of mitogen-activated protein kinase in cerebral cortical explants: convergence of estrogen and neurotrophin signaling pathways. Journal of Neuroscience 19 1179-1188.

Sitruk-Ware R \& El-Etr M 2013 Progesterone and related progestins: potential new health benefits. Climacteric 16 69-78. (https://doi.org/1 0.3109/13697137.2013.802556)

Smith SS 1991 Progesterone administration attenuates excitatory amino acid responses of cerebellar Purkinje cells. Neuroscience 42 309-320. (https://doi.org/10.1016/0306-4522(91)90377-Z)

Su C, Cunningham RL, Rybalchenko N \& Singh M 2012 Progesterone increases the release of brain-derived neurotrophic factor from glia via progesterone receptor membrane component 1 (Pgrmc1)dependent ERK5 signaling. Endocrinology 153 4389-4400. (https://doi. org/10.1210/en.2011-2177)

Suzuki S, Brown CM, Dela Cruz CD, Yang E, Bridwell DA \& Wise PM 2007 Timing of estrogen therapy after ovariectomy dictates the efficacy of its neuroprotective and antiinflammatory actions. PNAS $\mathbf{1 0 4}$ 6013-6018. (https://doi.org/10.1073/pnas.0610394104)

Tang H, Zhang Q, Yang L, Dong Y, Khan M, Yang F, Brann DW \& Wang R 2014 GPR30 mediates estrogen rapid signaling and neuroprotection. Molecular and Cellular Endocrinology 387 52-58. (https://doi. org/10.1016/j.mce.2014.01.024)

Thomas P 2008 Characteristics of membrane progestin receptor alpha (mPRalpha) and progesterone membrane receptor component 1 (PGMRC1) and their roles in mediating rapid progestin actions. Frontiers in Neuroendocrinology 29 292-312. (https://doi.org/10.1016/j. yfrne.2008.01.001)

Thomas P \& Pang Y 2012 Membrane progesterone receptors: evidence for neuroprotective, neurosteroid signaling and neuroendocrine functions in neuronal cells. Neuroendocrinology 96 162-171. (https:// doi.org/10.1159/000339822)

Thomas P, Pang Y, Filardo EJ \& Dong J 2005 Identity of an estrogen membrane receptor coupled to a $\mathrm{G}$ protein in human breast cancer cells. Endocrinology 146 624-632. (https://doi.org/10.1210/en.20041064)

Toran-Allerand CD, Singh M \& Sétáló Gr Jr 1999 Novel mechanisms of estrogen action in the brain: new players in an old story.
Frontiers in Neuroendocrinology 20 97-121. (https://doi.org/10.1006/ frne.1999.0177)

Toran-Allerand CD, Guan X, MacLusky NJ, Horvath TL, Diano S, Singh M, Connolly ES, Nethrapalli IS \& Tinnikov AA 2002 ER-X: a novel, plasma membrane-associated, putative estrogen receptor that is regulated during development and after ischemic brain injury. Journal of Neuroscience 22 8391-8401.

Toung TJK, Traystman RJ \& Hurn PD 1998 Estrogen-mediated neuroprotection after experimental stroke in male rats. Stroke 29 1666-1670. (https://doi.org/10.1161/01.STR.29.8.1666)

Tsutsui K 2006 Biosynthesis and organizing action of neurosteroids in the developing Purkinje cell. Cerebellum 5 89-96. (https://doi. org/10.1080/14734220600697211)

Tsutsui K 2012 Neurosteroid biosynthesis and action during cerebellar development. Cerebellum 11 414-415. (https://doi.org/10.1007/ s12311-011-0341-7)

VanLandingham JW, Cekic M, Cutler S, Hoffman SW \& Stein DG 2007 Neurosteroids reduce inflammation after TBI through CD55 induction. Neuroscience Letters 425 94-98. (https://doi.org/10.1016/j. neulet.2007.08.045)

Varea O, Garrido JJ, Dopazo A, Mendez P, Garcia-Segura LM \& Wandosell F 2009 Estradiol activates $\beta$-catenin dependent transcription in neurons. PLOS ONE 4 e5153. (https://doi.org/10.1371/ journal.pone.0005153)

Varea O, Arevalo M-A, Garrido JJ, Garcia-Segura LM, Wandosell F \& Mendez P 2010 Interaction of estrogen receptors with insulin-like growth factor-I and Wnt signaling in the nervous system. Steroids $\mathbf{7 5}$ 565-569. (https://doi.org/10.1016/j.steroids.2009.09.006)

Varea O, Escoll M, Diez H, Garrido JJ \& Wandosell F 2013 Oestradiol signalling through the Akt-mTORC1-S6K1. Biochimica et Biophysica Acta 1833 1052-1064. (https://doi.org/10.1016/j.bbamcr.2012.12.019)

Vegeto E, Belcredito S, Ghisletti S, Meda C, Etteri S \& Maggi A 2006 The endogenous estrogen status regulates microglia reactivity in animal models of neuroinflammation. Endocrinology 147 2263-2272. (https:// doi.org/10.1210/en.2005-1330)

Vegeto E, Benedusi V \& Maggi A 2008 Estrogen anti-inflammatory activity in brain: a therapeutic opportunity for menopause and neurodegenerative diseases. Frontiers in Neuroendocrinology 29 507-519. (https://doi.org/10.1016/j.yfrne.2008.04.001)

Von Schassen C, Fester L, Prange-Kiel J, Lohse C, Huber C, Böttner M \& Rune GM 2006 Oestrogen synthesis in the hippocampus: role in axon outgrowth. Journal of Neuroendocrinology 18 847-856. (https://doi. org/10.1111/j.1365-2826.2006.01484.x)

Wang C, Zhang F, Jiang S, Siedlak SL, Shen L, Perry G, Wang X, Tang B \& Zhu X 2016 Estrogen receptor-alpha is localized to neurofibrillary tangles in Alzheimer's disease. Scientific Reports 6 20352. (https://doi. $\operatorname{org} / 10.1038 /$ srep20352)

Wharton W, Baker LD, Gleason CE, Dowling M, Barnet JH, Johnson S, Carlsson C, Craft S \& Asthana S 2011 Short-term hormone therapy with transdermal estradiol improves cognition for postmenopausal women with Alzheimer's disease: results of a randomized controlled trial. Journal of Alzheimer's Disease 26 495-505. (https://doi. org/10.3233/JAD-2011-110341)

Wijayaratne AL \& McDonnell DP 2001 The human estrogen receptoralpha is a ubiquitinated protein whose stability is affected differentially by agonists, antagonists, and selective estrogen receptor modulators. Journal of Biological Chemistry 276 35684-35692. (https:// doi.org/10.1074/jbc.M101097200)

Wise PM 2003 Impact of menopause on the brain. Alzheimer Disease and Associated Disorders 17 S48-S50.

Woolley CS \& McEwen BS 1993 Roles of estradiol and progesterone in regulation of hippocampal dendritic spine density during the estrous cycle in the rat. Journal of Comparative Neurology 336 293-306. (https://doi.org/10.1002/cne.903360210)

Wright DW, Bauer ME, Hoffman SW \& Stein DG 2001 Serum progesterone levels correlatewith decreased cerebral edema 
aftertraumatic brain injury in male rats. Journal of Neurotrauma 18 901-909. (https://doi.org/10.1089/089771501750451820)

Xu H, Gouras GK, Greenfield JP, Vincent B, Naslund J, Mazzarelli L, Fried G, Jovanovic JN, Seeger M, Relkin NR, et al. 1998 Estrogen reduces neuronal generation of Alzheimer beta-amyloid peptides. Nature Medicine 4 447-451. (https://doi.org/10.1038/nm0498-447)

Yague JG, Munoz A, de Monasterio-Schrader P, Defelipe J, GarciaSegura LM \& Azcoitia I 2006 Aromatase expression in the human temporal cortex. Neuroscience 138 389-401. (https://doi.org/10.1016/j. neuroscience.2005.11.054)

Yao J, Chen S, Cadenas E \& Brinton RD 2011 Estrogen protection against mitochondrial toxin-induced cell death in hippocampal neurons: antagonism by progesterone. Brain Research 1379 2-10. (https://doi. org/10.1016/j.brainres.2010.11.090)

York B \& O'Malley BW 2010 Steroid receptor coactivator (SRC) family: masters of systems biology. Journal of Biological Chemistry $\mathbf{2 8 5}$ 38743-38750. (https://doi.org/10.1074/jbc.R110.193367)

Zhang QG, Wang R, Khan M, Mahesh V \& Brann DW 2008 Role of Dickkopf-1, an antagonist of the Wnt/beta-catenin signaling pathway, in estrogen-induced neuroprotection and attenuation of tau phosphorylation. Journal of Neuroscience 28 8430-8441. (https://doi. org/10.1523/JNEUROSCI.2752-08.2008)
Zhang B, Subramanian S, Dziennis S, Jia J, Uchida M, Akiyoshi K, Migliati E, Lewis AD, Vandenbark AA, Offner H, et al. 2010 Estradiol and G1 reduce infarct size and improve immunosuppression after experimental stroke. Journal of Immunology 184 4087-4094.

Zhao L \& Brinton RD 2007 Estrogen receptor alpha and beta differentially regulate intracellular $\mathrm{Ca}(2+)$ dynamics leading to ERK phosphorylation and estrogen neuroprotection in hippocampal neurons. Brain Research 1172 48-59. (https://doi.org/10.1016/j. brainres.2007.06.092)

Zhu Y, Rice CD, Pang Y, Pace M \& Thomas P 2003a Cloning, expression, and characterization of a membrane progestin receptor and evidence it is an intermediary in meiotic maturation of fish oocytes. PNAS $\mathbf{1 0 0}$ 2231-2236. (https://doi.org/10.1073/pnas.0336132100)

Zhu Y, Rice CD, Pang Y, Pace M \& Thomas P 2003b Cloning, expression, and characterization of a membrane progestin receptor and evidence it is an intermediary in meiotic maturation of fish oocytes. PNAS $\mathbf{1 0 0}$ 2231-2236. (https://doi.org/10.1073/pnas.0336132100)

Zuloaga DG, Yahn SL, Pang Y, Quihuis AM, Oyola MG, Reyna A, Thomas P, Handa RJ \& Mani SK 2012 Distribution and estrogen regulation of membrane progesterone receptor- $\beta$ in the female rat brain. Endocrinology 153 4432-4443. (https://doi.org/10.1210/ en.2012-1469)

Received in final form 20 February 2018

Accepted 19 March 2018

Accepted Preprint published online 19 March 2018
๑) 2018 Society for Endocrinology Published by Bioscientifica Ltd. 